\title{
دور الإعلان الإذاعي في تعزيز قرارات الشراء لدى المواطن العراقي
}

أ.م.د محمد رشك كاظم أبـ

كلية الإدارة والاقتصاد / الجامعة المستنصرية مدمد رلتص
كلية الآداب / مثد. مدين عمران التمبيمي

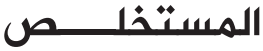

يرمي هذا البحث إلى معرفة دور الإعلان الإذاعي في تعريز قرارات الشراء لدى المواطن

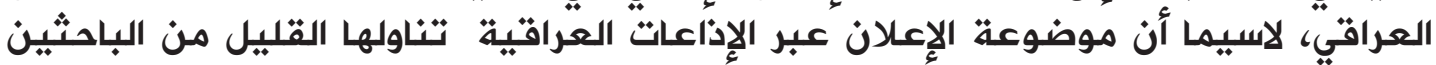
العراقبينه، وهدف البحث إلى معرفة حجم تعرض الجمهور للإعلان الإذاعي عبر الاذأاعات العراقية وأنماط ذلك التعرض، والكشف عن أسباب استماع الجمهور للإعلإن الإذاعبي، وتصديد

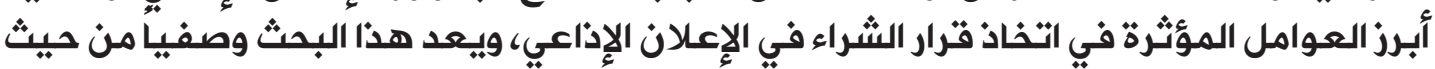
النوع, إذ استخدم الباحث المنهج المسحي، والاستبانت والمقباس لجمع البيانات والمعلومات, وتم اختبار العينة على وفنق أسلوب العينة العمدية، وبلغ حجم عبنة البحث المبيداني (•0)

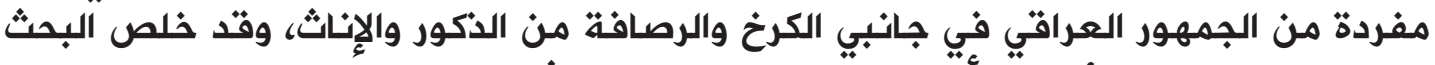
إلى مجموعة من النتائج من أهمها، تعد الاذاعة مصدر ثقةت لدى الجمهور العراقي لانها غئير مضللة وتسهم في ايصـال المعلومات عن السلع المعلن منه عنها وكذلك في شراء الضروري منها، وان مدة عرض البرامج الاذاعية هي افضل الاوقات لبث الاعلان الإن الاذاعي لكثرة الاستماع اليها

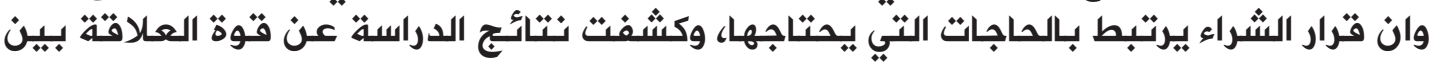

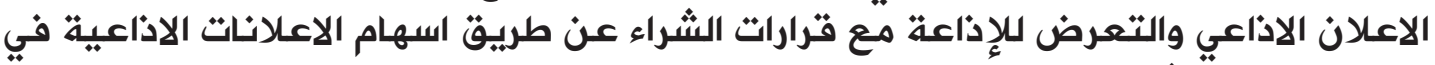
تصديد قرارات الشراء لما تقدمة تلك الاعلانات من معلومات عن السلع المعلن عنها لغرض

جدب الانتباه واقنتناء السلعة.

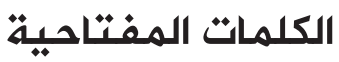

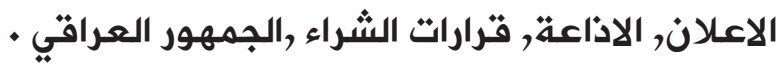

The role of radio advertising in promoting purchasing decisions of Iraqi citizens

.ASS.PROF PHD

MOHAMMED RASHAK KADHIM ALESSA

Email;dr_alessa@yahoo.com

- LAC.PHD

MEDIAN UMRAN ALTIMEEMI

Email;Med_mas76@yahoo.com

Abstract

This research aims to identify the role of radio advertising in promoting pur- 
chasing decisions of Iraqi audiences, especially that the placement of the announcement through the Iraqi radio stations dealt with a little of Iraqi researchers, and the goal of the research to know the extent of public exposure to the radio advertising through Iraqi radio and patterns of exposure,disclosure of the reasons for public hearing of the radio advertisement, identifying the most important factors influencing the decision to buy in the radio advertisement, this research is descriptive in terms of type as the researcher used the survey method,questionnaire and scale for data and information collection, the sample was selected according to the purposive sample method, and the sample size of the field research (500) individual from the Iraqi public in both sides of Karkh and Rusafa male and female, the research concluded a series of results, the most important of which,the radio is a source of confidence among the Iraqi audiences because it is not misleading and contributes to the delivery of information about the declared goods as well as the purchase of necessary, and that the period of presentation of radio programs is the best times to broadcast the radio advertisement for the great listening and the decision to buy is related to the needs that the public needs, the results of the study also revealed the strength of the relationship between radio advertising and exposure to radio with purchasing decisions through the contribution of radio advertising in determining the purchase decisions for the advertisement of such information about the goods advertised in order to attract audiences attention to the acquisition of the commodity

Key words: Advertising,Rado,Purchase Decisions, The Iraqi public

المقدمة :

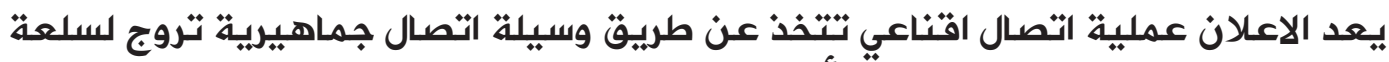

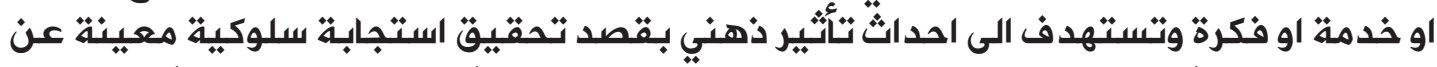

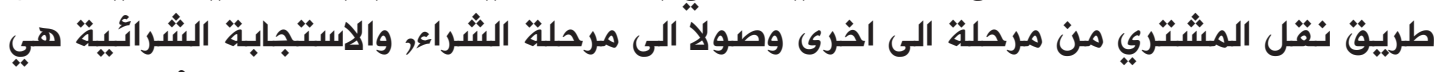

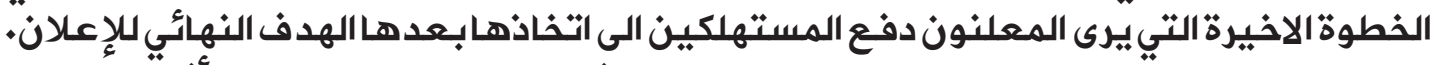

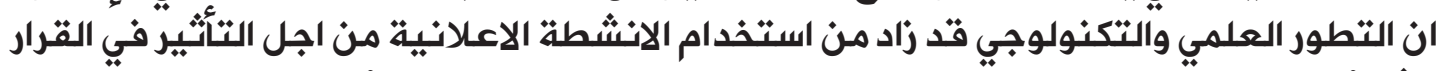

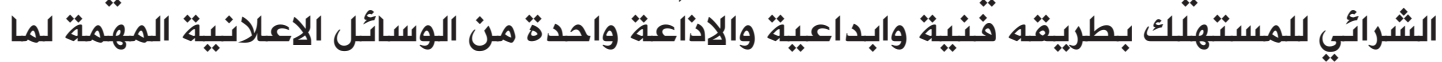

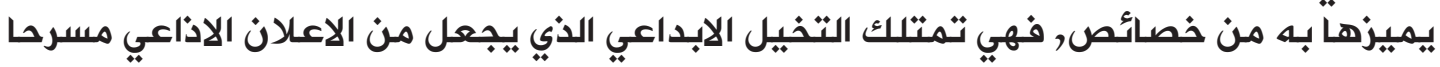

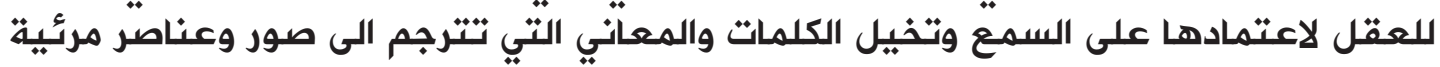

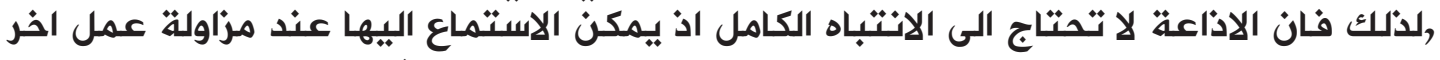

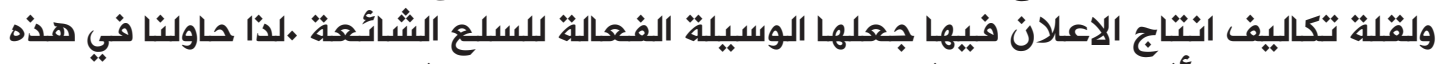

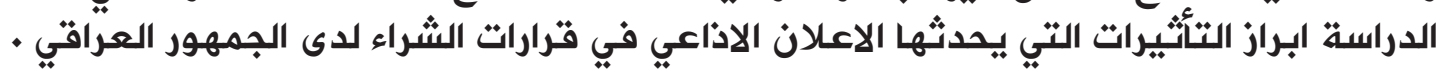




\section{الاطار المنهجي للبحث}

أولا:مشكلة البحث: المستهلكين من هذه السلع المعروضة، لذّلك تقدم الرسالة الإعلانية المعلومات المفتلفة

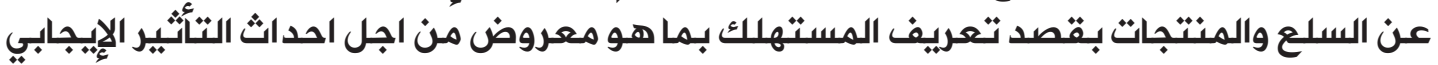
على المستهلك واقناعه بما بـقدم من اعلان لدفعه الى شراء السلـع المعلن عنها، فـالرسالة

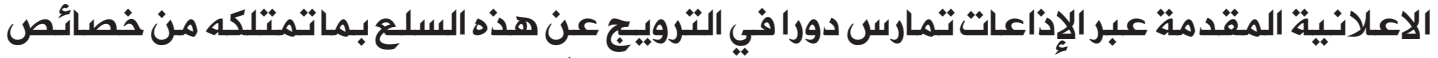
كبقبة الوسائل الإعلامبية الاخر لانها تخاطب الاعمار والثقافات المختلفته، وفي ضوء ما سبق

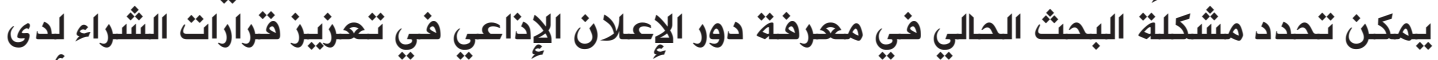

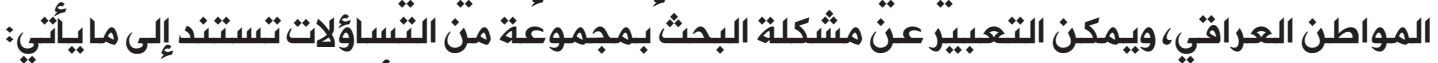

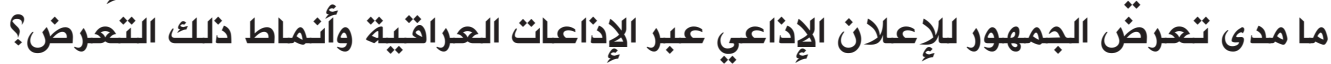

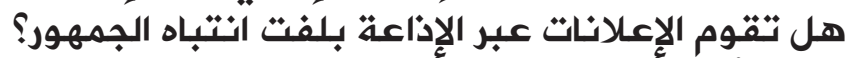

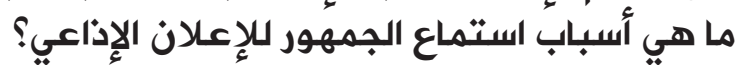

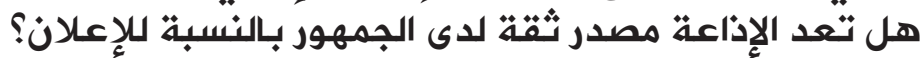

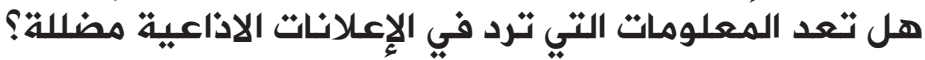

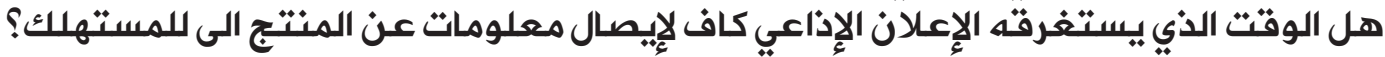

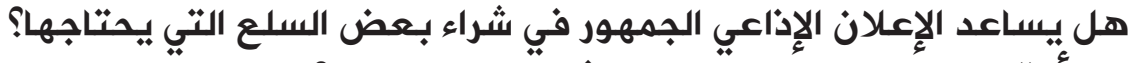

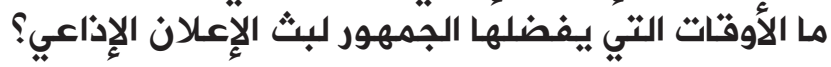

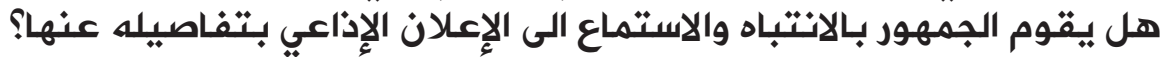

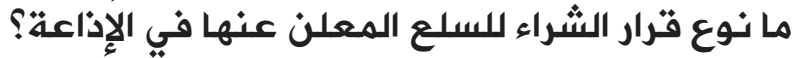

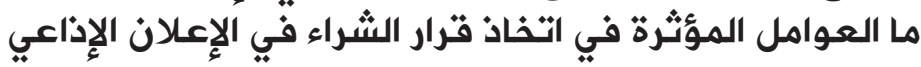

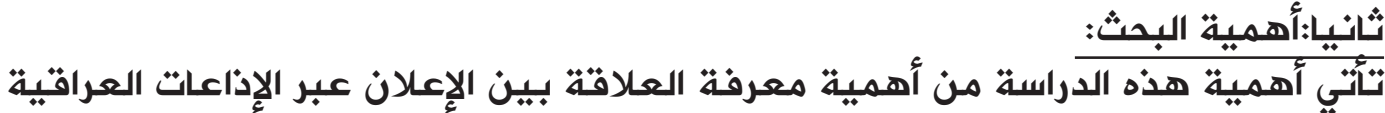
وقرارات الشراء لدى الجمهور العراقي، والذي بدوره يسـاعد العـاملبن على الإعـلانـات من تحديد

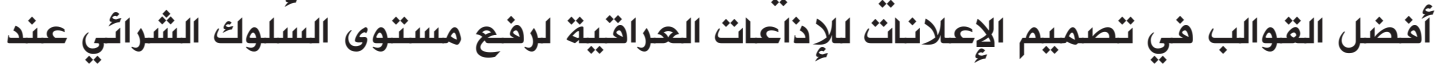

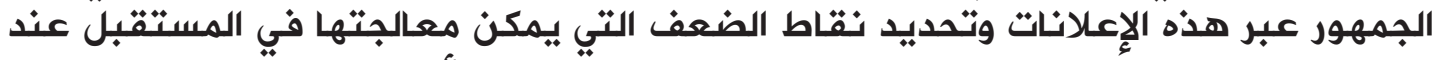

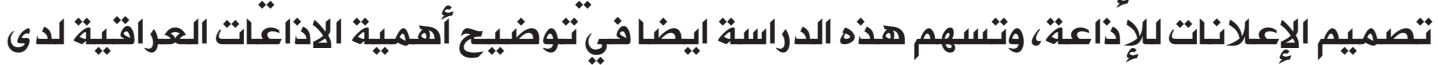

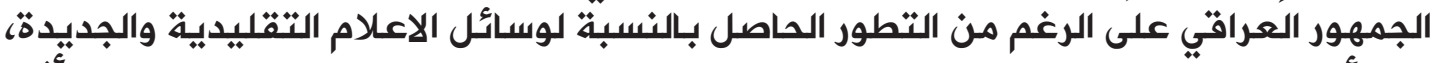

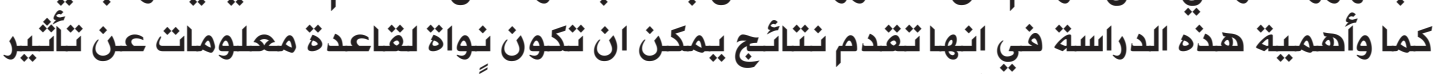

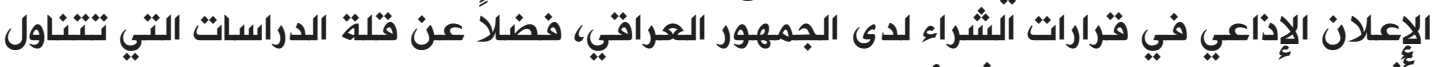

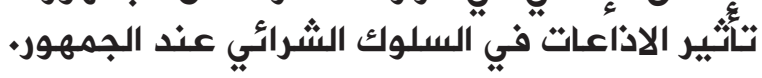

لكل بـثاً: اهد افث البحث: علمي اهداف يسعى لتحقيقها عن طريـق الدراسة ويمكن تحديد اهداف هذا البحث ضمن 
النقاط الاتية:

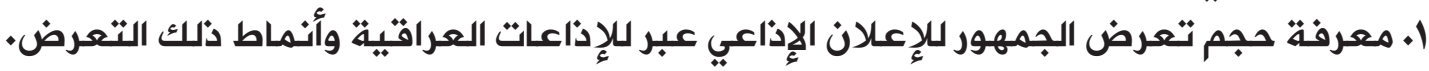

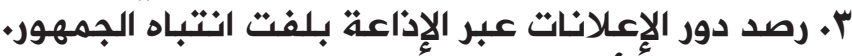

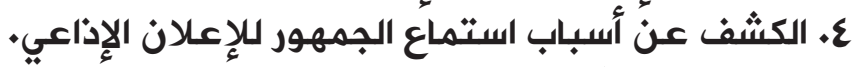

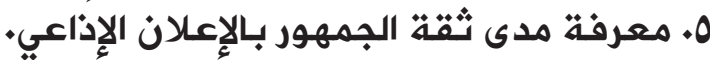

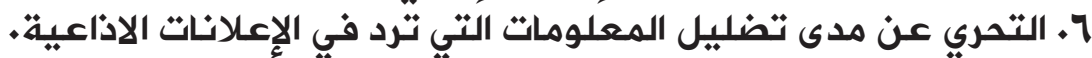

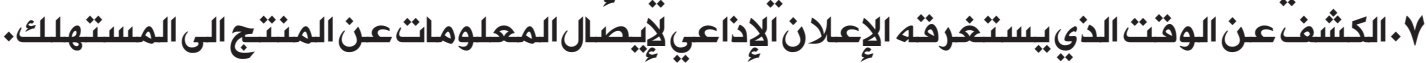

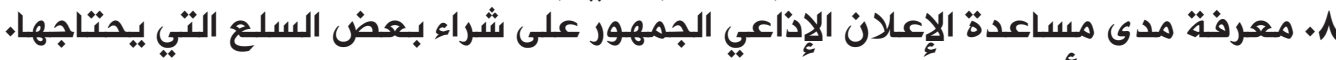

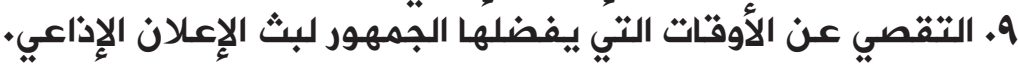

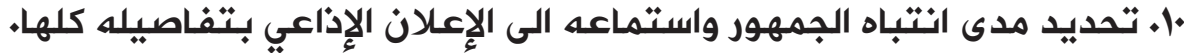

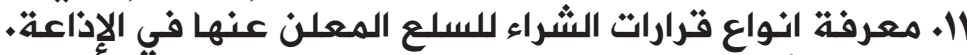

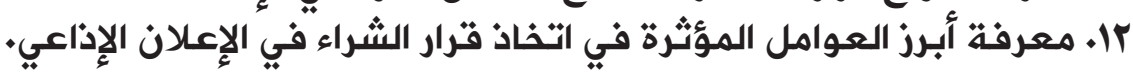

بـناء؛ على المحاؤ فروض البحث:

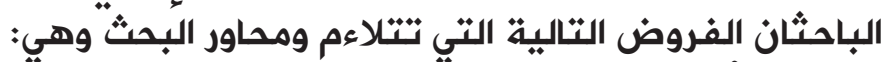

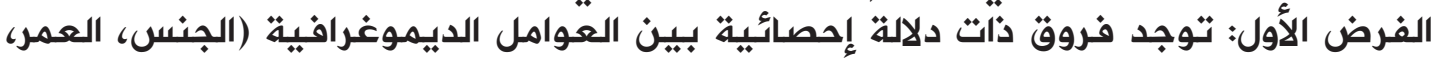

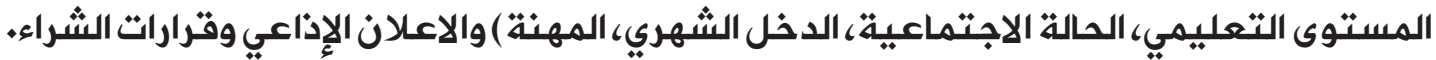

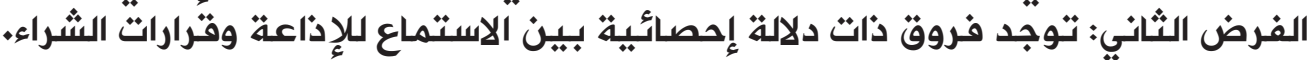

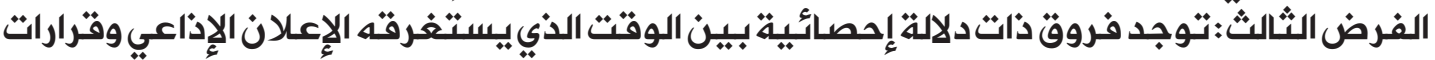
الشراء. الفرض الرابع: توجد فروق ذات دلالة إحصائية بين التعرض المستمر للإعلان الإذاعي وقرارات الشراء. الفرض الخامس: توجد فروق ذات دلالة إحصائية بين مدى ثقة الجمهور بالإعلانات الاذاعية وقرارات الشراء. الفرض السادس: توجد فروق ذات أتراء دلالة إحصائية بين المعلومات الواردة في الإعلانات الاذاعية وقرارات الشراء الفرض السابـع: توجد فروق ذات دلالة إحصائية بين مساعدة الإعلان الإذأعي الجمهور في التعرف

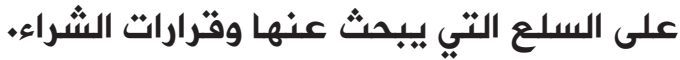

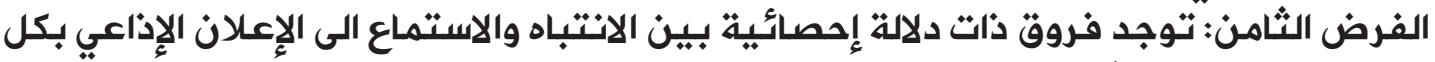

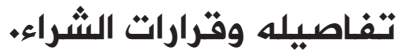
الفرض التاسع: توجد فروق ذات دلالة إحصائية بين قراء الإدار الشراء للسلع المعلن عنها في الإذاعة

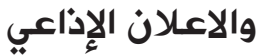
الفرض العاشر: تُوجد فروق ذإِات دلالة إحصائية بين العوامل المؤثرة على اتخاذ قرار الشراء والاعلان الإذاعي 
الفرضالحادي عشر:لاتوجد فروق ذاتدلالة إحصائية بين المكان الذي يستمع فيه الجمهورللإعلان الاذاعي وقرارات الشراء

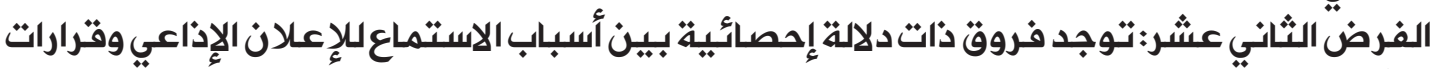

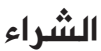

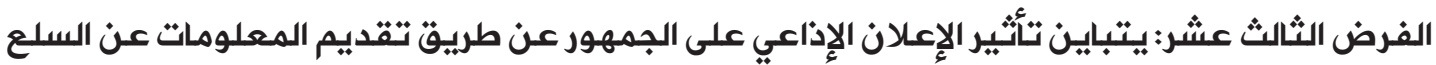

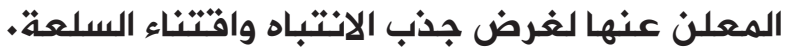

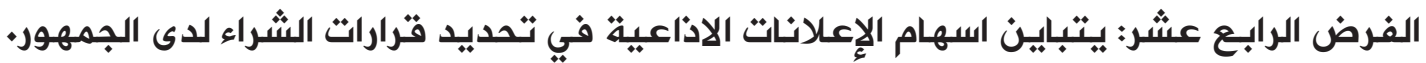

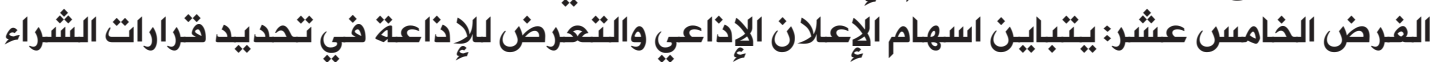
لدى الجمهور العراقي.

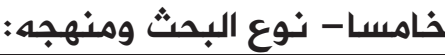

تنتمي هذ الدراسة من حيث النهاث النوع الى الدراسات الوصفية التي تعنى بدراسة الجمهور

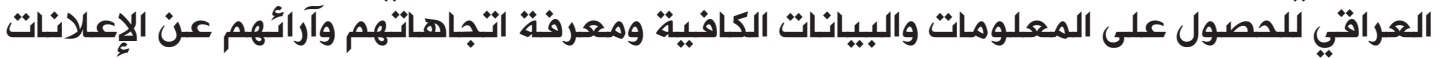

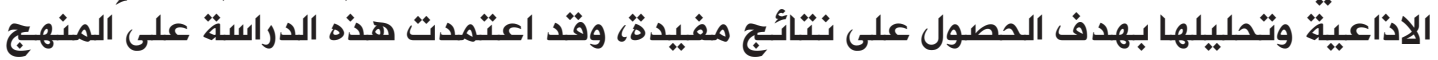

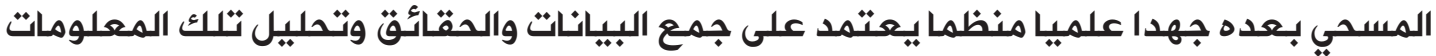

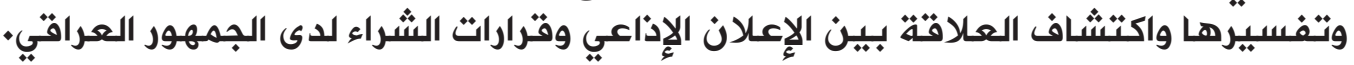

سادسا- طرق البحث وادواته : استخدم البحث مجموعة من الطرة البات والأدوات البات العلمية في السياق الميداني للبحث وكالاتي:

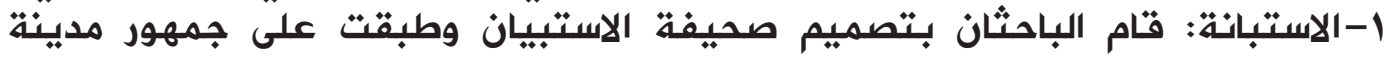

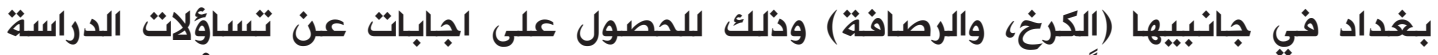

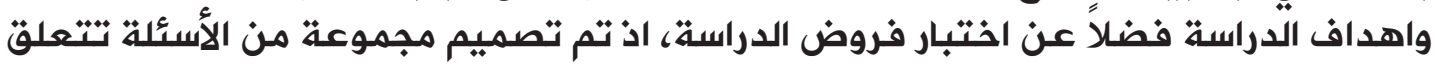

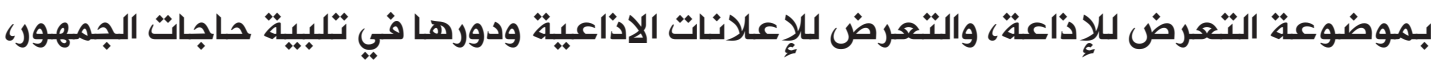

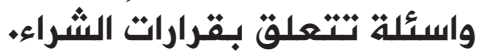

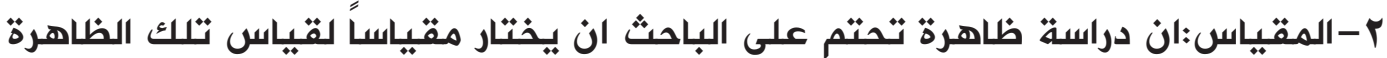

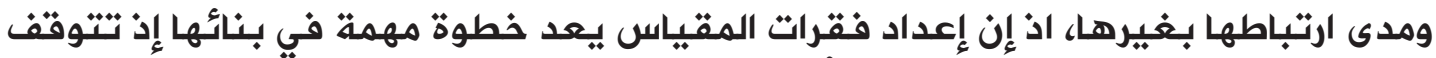

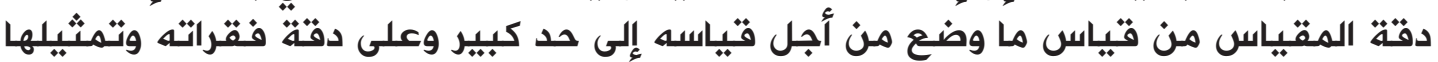

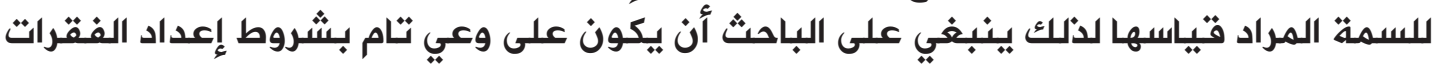

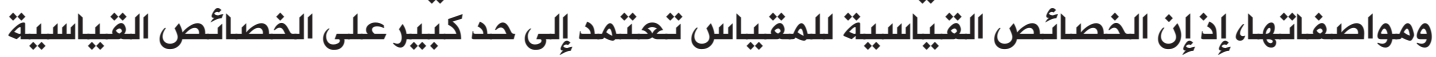
للفقرات (Abdul Rahman Saad,1983,p-240)

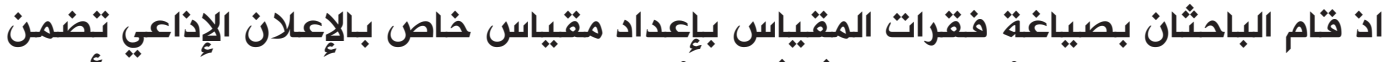

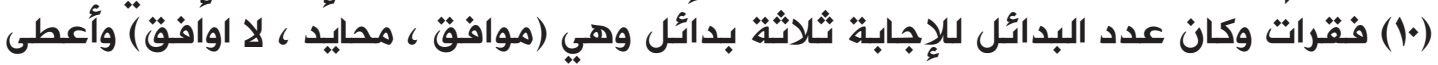

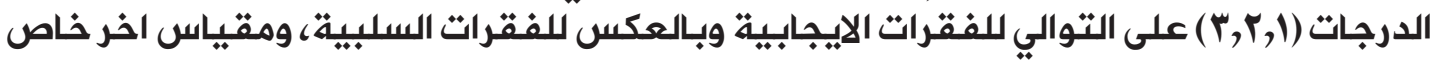

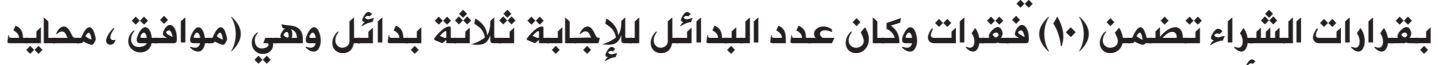

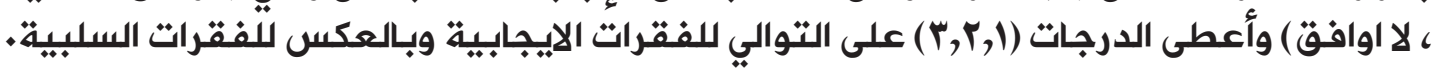




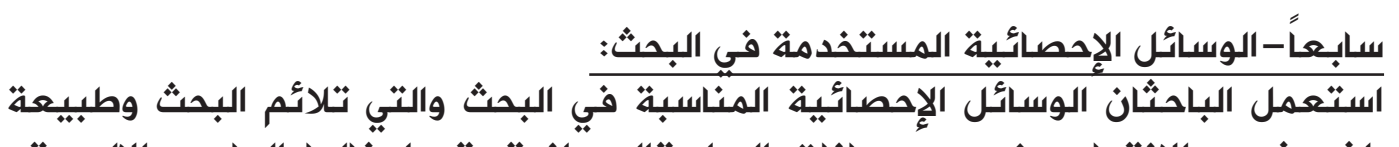

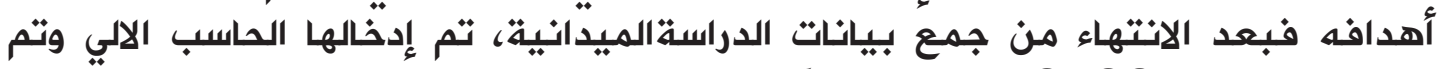

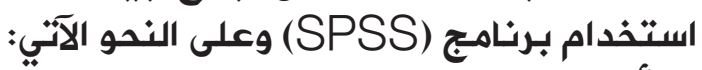
أ- التكرارات البسيطة والنسب النسب المئوية.

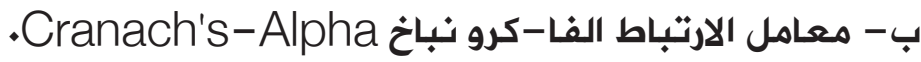
ج - التجزئة النصفية الارتباطية

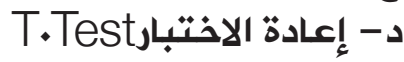

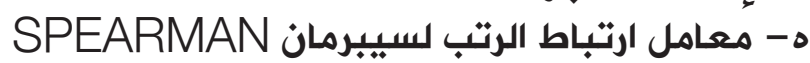

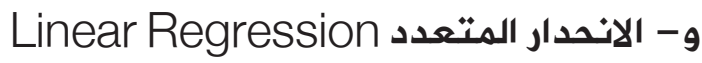

ثـامناًا مجتمع البحث وعينته:

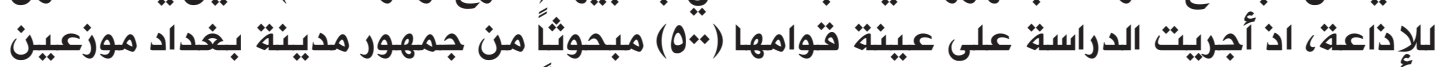

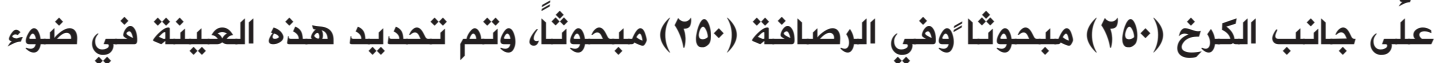

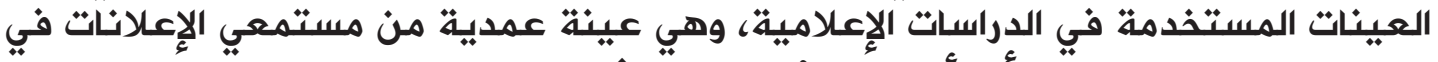

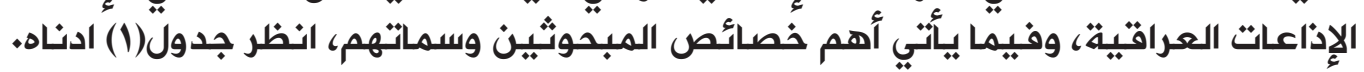


جدول (1) حسب خصائص المبحوثين وسماتهم

\begin{tabular}{|c|c|c|c|c|c|}
\hline \multicolumn{2}{|c|}{ المجمــــوع } & النسبة المئوية & 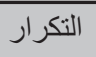 & البيانـــات & 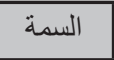 \\
\hline \multirow[t]{2}{*}{$\% 1 \ldots$} & \multirow[t]{2}{*}{$\% 1 \ldots$} & $\% 07$ & rA. & 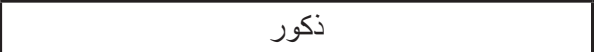 & \multirow[t]{2}{*}{ 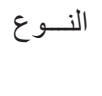 } \\
\hline & & $\% \varepsilon \varepsilon$ & rr. & اناث & \\
\hline \multirow{5}{*}{$\% 1 \ldots$} & \multirow{5}{*}{$\% 1 \ldots$} & $\%(, \varepsilon$ & $1 \cdot v$ & ه اسنة الى 0Y سنة & \multirow{5}{*}{ متغير } \\
\hline & & $\% ґ \wedge, \varepsilon$ & 194 & بَ سنة الى هب سنة & \\
\hline & & $\% 71$ & 100 & بr سنة الى 0؛ سنة & \\
\hline & & $\%, \uparrow$ & $\varepsilon r$ & 1 كـ سنة الى 00 سنة & \\
\hline & & $\% \cdot, 7$ & $r$ & 00 سنة فأكثر & \\
\hline \multirow{3}{*}{$\% 1 \ldots$} & \multirow{3}{*}{$\% 1 \ldots$} & $\% 11, \wedge$ & 09 & 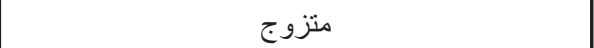 & \multirow{3}{*}{ الاجتماعية } \\
\hline & & $\% \wedge 0, r$ & $\varepsilon r q$ & اعزب اعب & \\
\hline & & $\%$ & 10 & مطلق & \\
\hline \multirow{7}{*}{$\% 1 \ldots$} & \multirow{7}{*}{$\% 1 \ldots$} & $\% \leqslant \varepsilon$ & rr. & موظف & \multirow{7}{*}{ المهنـــة } \\
\hline & & $\% 10, \varepsilon$ & $\checkmark V$ & كاسب & \\
\hline & & $\% 1 \leq$ & $v \cdot$ & طالب & \\
\hline & & $\%$ & 77 & ربة بيت & \\
\hline & & $\%\urcorner, 7$ & 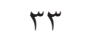 & 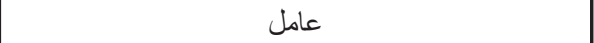 & \\
\hline & & $\%\urcorner, r$ & r & لا يعمل & \\
\hline & & $\% \cdot, 7$ & r & متقاعد & \\
\hline \multirow{7}{*}{$\% 1 \ldots$} & \multirow{7}{*}{$\% 1 \ldots$} & $\% 1, \varepsilon$ & $v$ & يقرأ ويكتب لم يكمل الدر اسة الابتدائية & \multirow{7}{*}{ الدر اسصيل } \\
\hline & & $\%, r$ & rt & الابتدائية & \\
\hline & & $\% \vee, \wedge$ & rq & المتوسطة & \\
\hline & & $\% 1 r, 7$ & r & 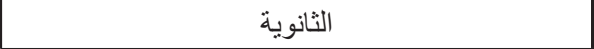 & \\
\hline & & $\% \wedge, r$ & «1 & 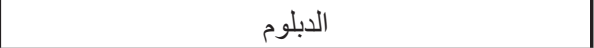 & \\
\hline & & $\% 09$ & r9o & 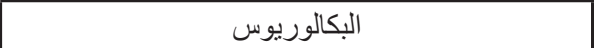 & \\
\hline & & $\%, \wedge$ & rq & شهادة عليا (دبلوم عالي, ماجستير, دكتور اه) & \\
\hline \multirow{5}{*}{$\% 1 \ldots$} & \multirow{5}{*}{$\% 1 \ldots$} & $\% 10$ & vo & اقل من ·O ب ألف دينار شهرياً & \multirow{5}{*}{ الثهري } \\
\hline & & $\%$ & 170 & من •.0 Tالف إلى اقل من •.Vo ألف دينار شهريا & \\
\hline & & $\%$ \% & $\mid 11$ & 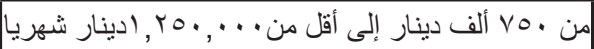 & \\
\hline & & $\%$ \% & ITr & 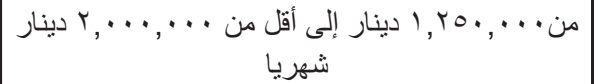 & \\
\hline & & $\% 1, r$ & 1 & 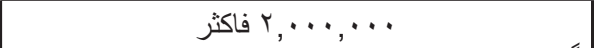 & \\
\hline
\end{tabular}

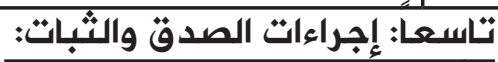

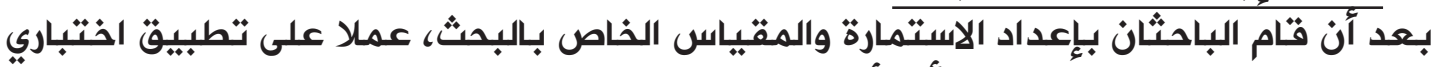

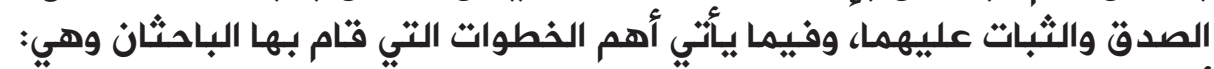

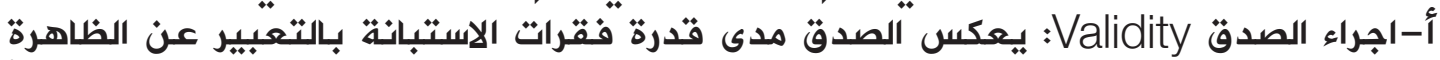

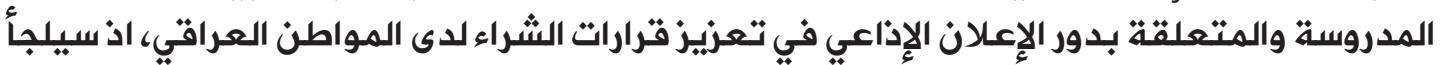




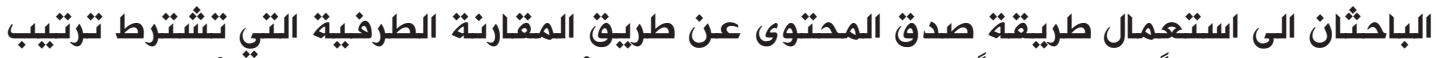

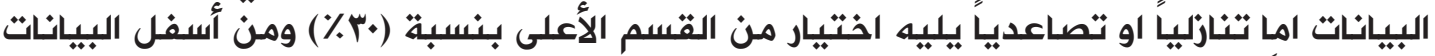

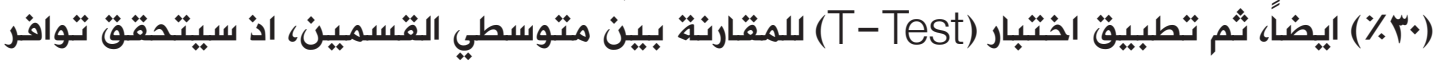

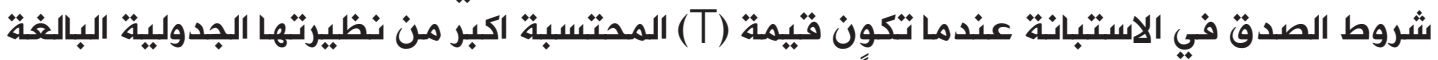

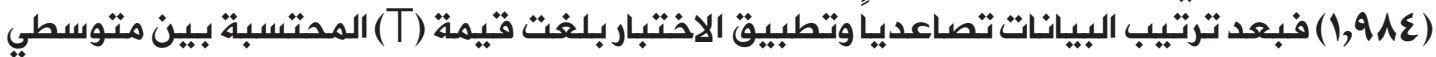

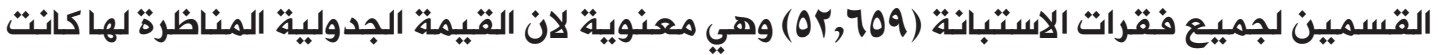

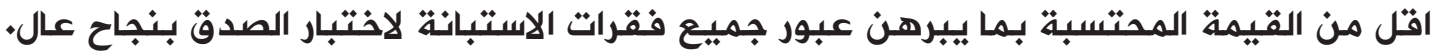

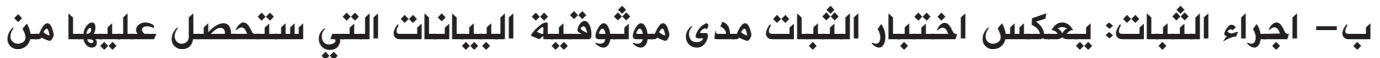

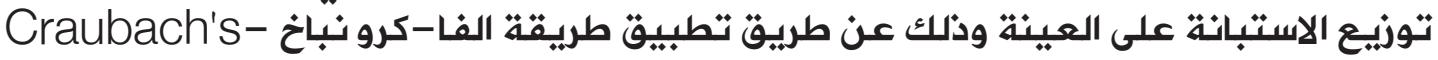
Alpha

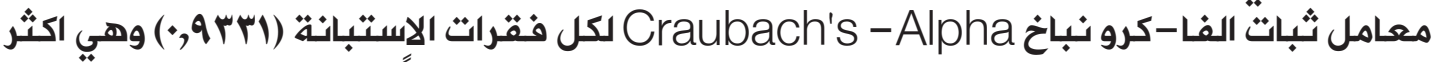

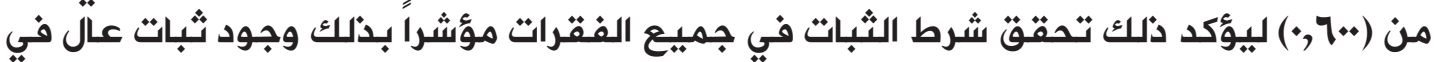

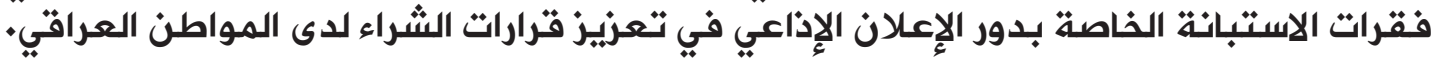

\section{عاشراً - حدود البحث ومجالاته:}

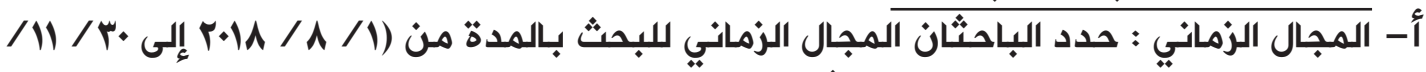

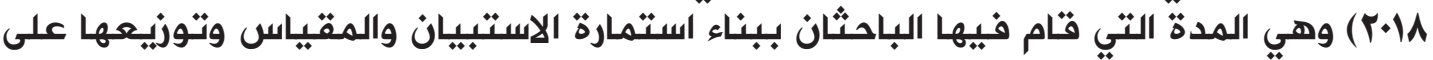
عينة البحث المتمثلة بجمهور مدينة بغداد فئهاد واسترجاعها.

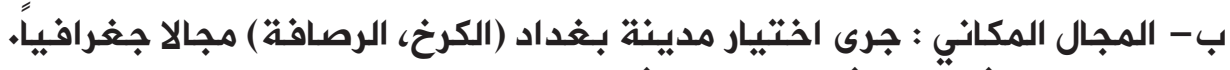

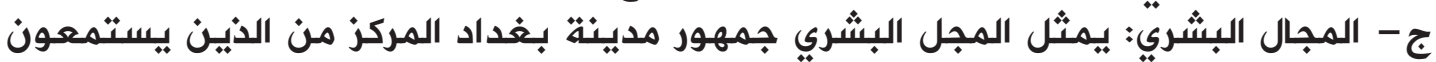
للإذذاعات العراقية.

احد عشر - تعريف المصطلحات:

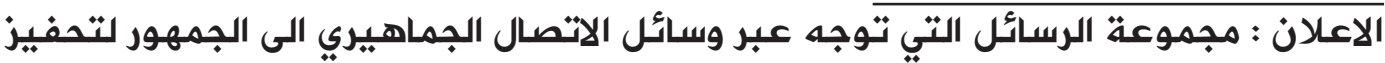

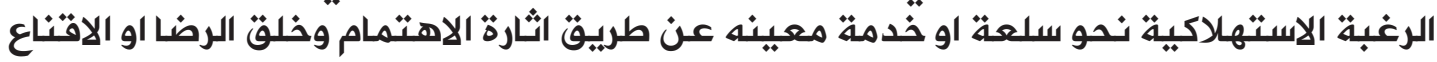

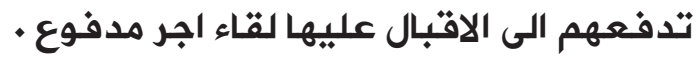

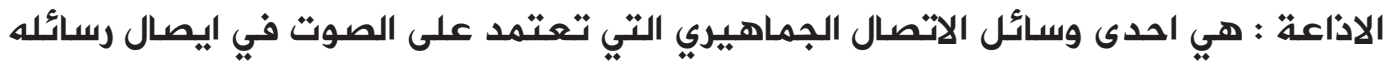

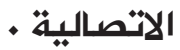

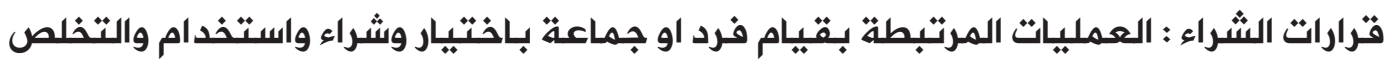

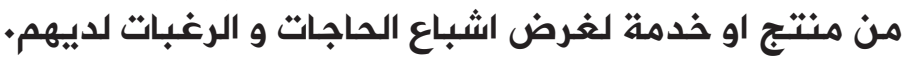

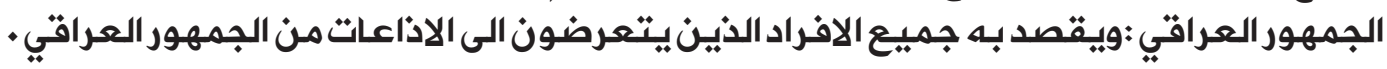

$$
\text { الدراسة الميدانية للبحث: تحليل نتائج الدراسة }
$$

$$
\text { المحور الأول : التعرض للإذذاعات العراقية: }
$$

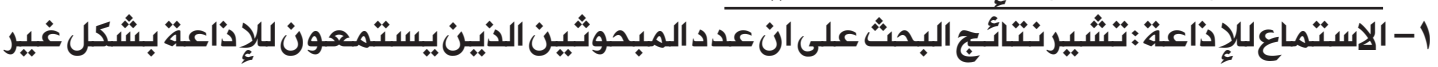


منتظم (احياناً) بـغ (YVY) مبحوثاً ويشكلون نسبة (Y00,\%) من مجموعة العينة، اما الذين يستمعون

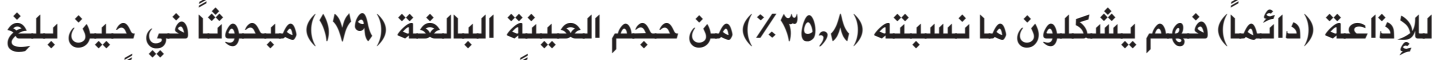

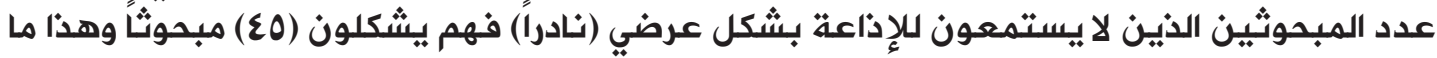
يشكل نسبة قيمتها(9٪) من حجم العينت، وهذا يدل على ان الجمهور العراقي مهتم بالاستماع للإذذاعة وبشكل منتظم على الرغم من وجود وسائل للاتصال اكثر تشويقـا من الإذاعة، وكما مبين في الجدول (r).

\begin{tabular}{|c|c|c|}
\hline النسبة المئوية & التكرارات & الاستماع للإذذاعة \\
\hline$\% 00, r$ & TrY & احياناً \\
\hline$\%$ ro, & IVq & دائماً \\
\hline$\% 9$ & عo & نادراً \\
\hline$\%$ & $0 .$. & المجمـــــــــوع \\
\hline
\end{tabular}

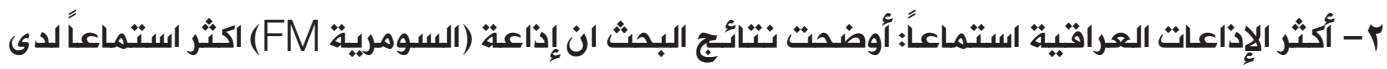
الجمهور العراقي لما تقدمه هذه الإذاعة من برامج متتنوعة ومشوقة تلإدة تلبي حاجـات الجمهور اذ شكلت ما

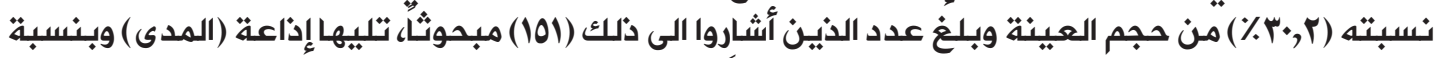

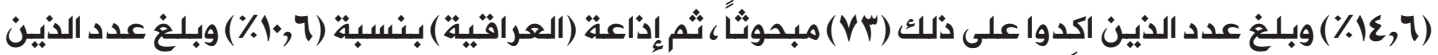

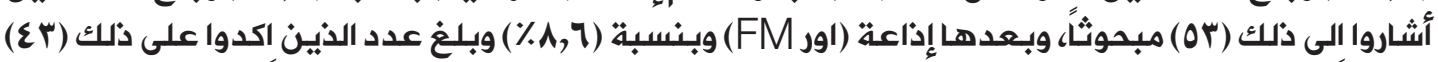

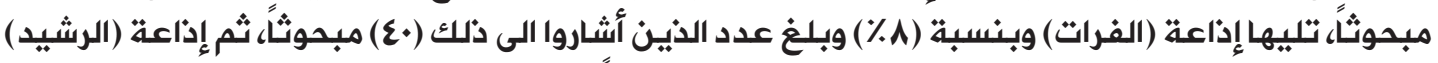

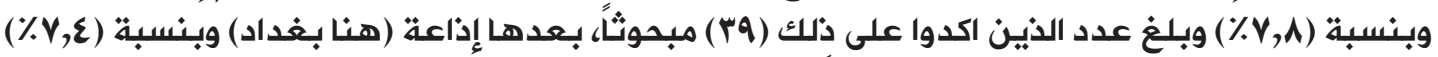

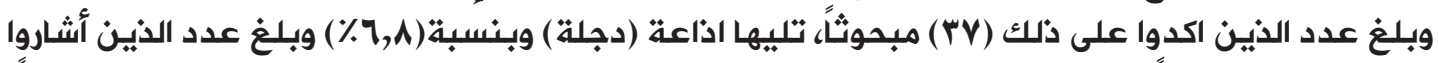

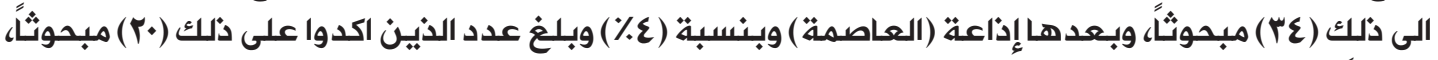
واخيراً إذاعة (العهد )وبنسبة ( (\%) وبلغ عدد الذين اكدوا على ذلك (•() مبحوثين. وكما مبين في الجدول (ץ). جدول (r) أكثر الإذاعات العراقبية استماعاً

\begin{tabular}{|c|c|c|}
\hline النسبة المئويـة & التكرارات & الإذاعات العراقية \\
\hline$\% r \cdot, r$ & 101 & السومرية \\
\hline \% , & vr & المدى \\
\hline$\% 1,7$ & or & العراقية \\
\hline$\% \wedge, 7$ & $\varepsilon r$ & اورJlm \\
\hline$\% \wedge$ & $\varepsilon$. & الفرات \\
\hline$\% \vee, \Lambda$ & ra & الرشيد \\
\hline$\% \vee, \varepsilon$ & rr & هنا بغداد \\
\hline$\%\urcorner, \wedge$ & $r \varepsilon$ & دجلة \\
\hline$\% \varepsilon$ & r. & العاصمة \\
\hline$\% r$ & 1. & العهد \\
\hline$\%$ & $0 .$. & المجموع \\
\hline
\end{tabular}


ץ- معدل الاستماع للإذاعة: افـاد المبحوثون انهم يستمعون للإذاعة (يومياً) والبالغ عددهم(بAl)

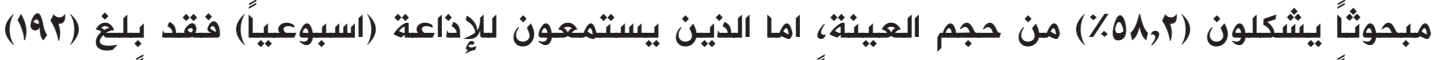

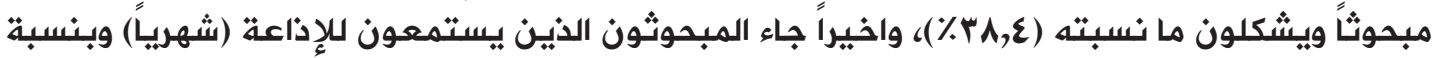

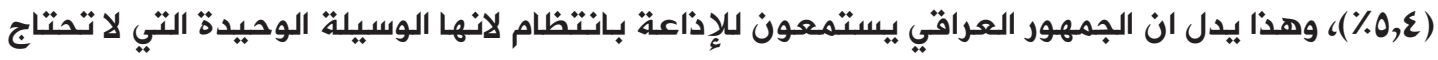

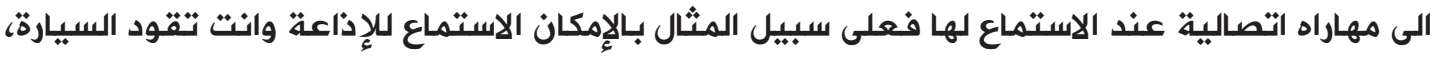
وكما مبين في الجدول (ع) مواه

جدول (ع) بـوضـح معدل الاستماع للإذذاعة

\begin{tabular}{|c|c|c|}
\hline النسبة المئوية & التكرارات & الاستماع للإذذاعة \\
\hline$\% 0 \Lambda, r$ & rAl & يومياً \\
\hline$\%$ \%^,乏 & 194 & اسبوعيا \\
\hline$\% 0, \varepsilon$ & rr & شهرياً \\
\hline$\%$ & $0 .$. & المجموع \\
\hline
\end{tabular}

ع- المدة التي يقضيها الجمهور في الاستماع للإذذاعة: تشير نتائج البحث الى ان معظم المبحوثين

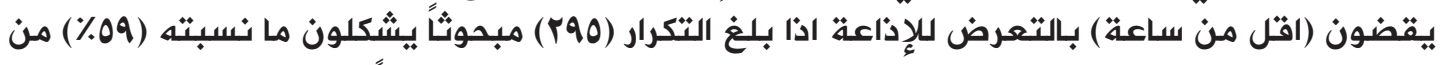

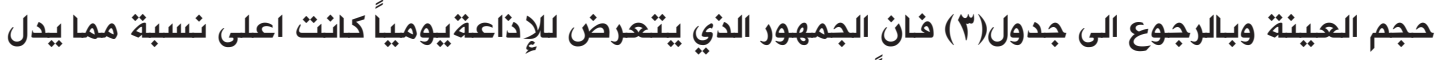

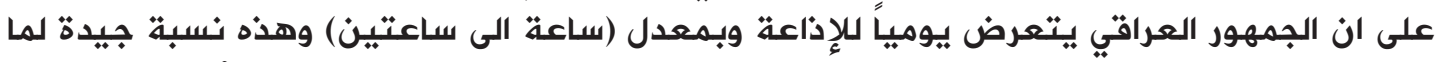
يتعرض الجمهور لبقية وسائل الاتصال الجماهيرية (التقليدية والصديثة)، في حين أشار المبحوثين ئين

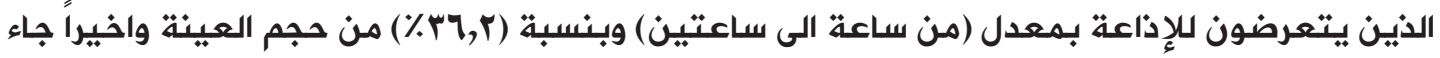

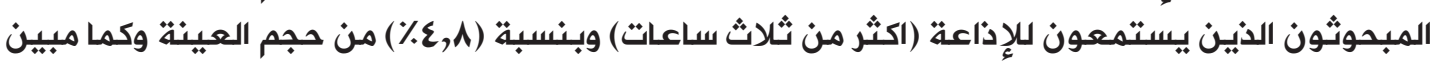

$$
\text { في الجدول(0). }
$$

جدول (0) يبوضع المدة التي بيقضيها الجمهور في الاستماع للإذاعة

\begin{tabular}{|c|c|c|}
\hline النسبة المئوية & التكرارات & لمدة التي يقضيها الجمهور \\
\hline$\% .09$ & ras & اقل من ساعة \\
\hline$\% r q, r$ & $|A|$ & من ساعة الى ساعتين \\
\hline$\% \varepsilon, \wedge$ & rع & اكثر من ثلاث ساعات \\
\hline$\%$ & $0 . \cdot$ & المجموع \\
\hline
\end{tabular}

0- الوقت المفضل للاستماع للإذاعة: أوضصت نتائج البحثان (الفترة الصباحية) افضل الاوقات

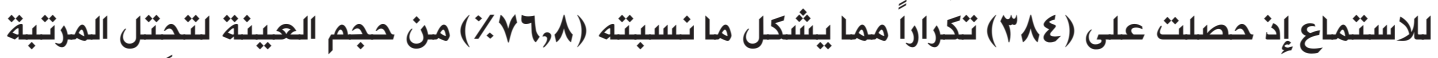
الاولى، اما (الفترة المسائية) فقد جاءت في المرتبة الثانية وقد حصلت على (OY) تكراراً مما يشكلٍ ما نسبته (1,1\%) من حجم العينة، في حين حصلت (فترة بعد منتصف الليل) على (عَ) تكرارا مما يشكل ما نسبته (1,^٪) لتحتل المرتبة الثالثة، اما المرتبة الرابعة فكانت (فترة الظهيرة) اذا

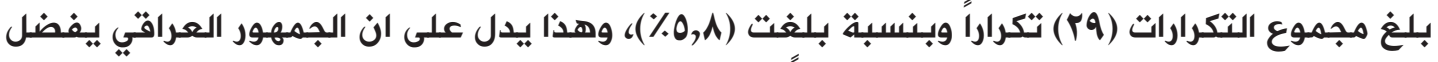

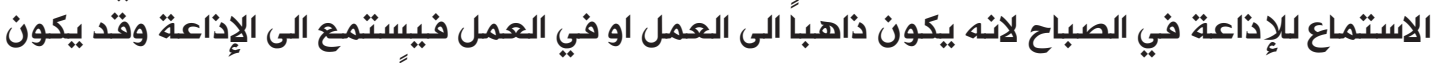

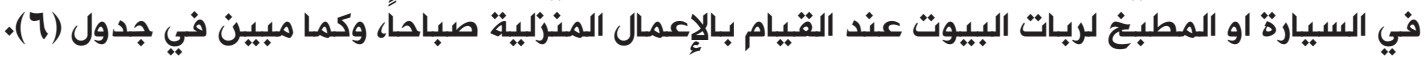


جدول (7) يوضح الفترة التي يفضلها الجمهور في الاستماع للإذاعة

\begin{tabular}{|c|c|c|}
\hline النسبة المئويـة & التكرارات & فترة الاستماع للإذاعة \\
\hline$\% \vee 7, \wedge$ & r^દ & الفترة الصباحية \\
\hline$\% 1,7$ & or & الفترة المسائية \\
\hline$\%\urcorner, \wedge$ & rع & فترة منتصف الليل \\
\hline$\% 0,1$ & ra & فترة الظهيرة \\
\hline$\%$ & $0 . \cdot$ & المجموع \\
\hline
\end{tabular}

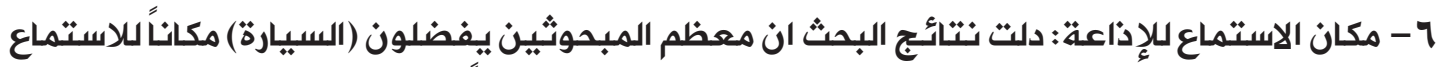

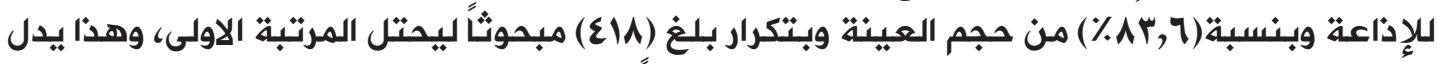

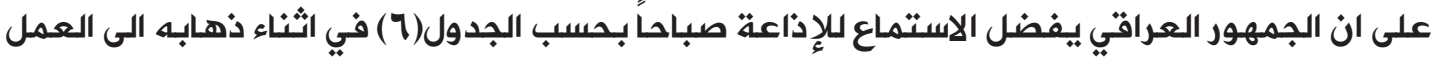

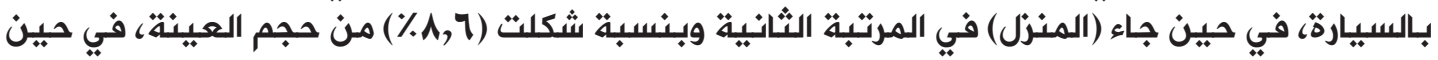

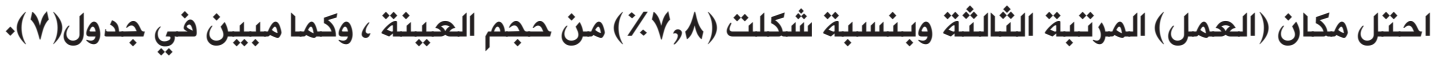

$$
\text { جدول (Y) يوضع مكان الاستماع للإذاعة }
$$

\begin{tabular}{|c|c|c|}
\hline النسبة المئويـة & التكرارات & مكان الاستماع للإذذاعة \\
\hline$\%$ Аr, 7 & EIA & السيارة \\
\hline$\% \wedge, 7$ & $\varepsilon r$ & المنزل \\
\hline$\% \vee, \Lambda$ & rq & العمل \\
\hline$\%$ & $0 . \cdot$ & المجموع \\
\hline
\end{tabular}

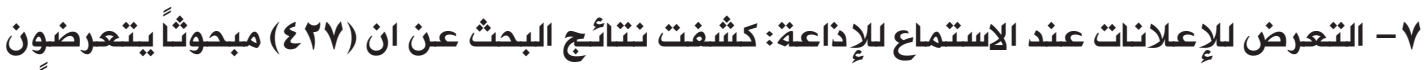

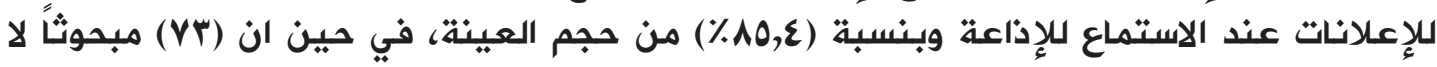

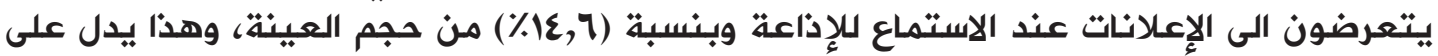

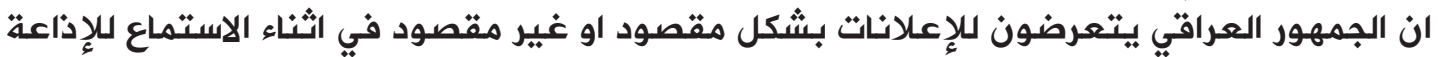

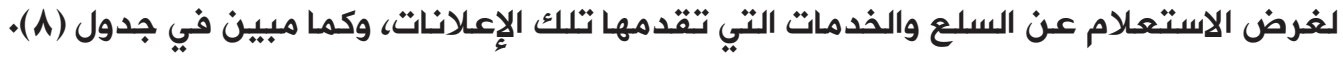
جدول (1) يوضح تعرض الجمهور للإعلانات عند الاستماع للإذاعة

\begin{tabular}{|c|c|c|}
\hline النسبة المئويـة & التكرارات & التعرض للإععلانات \\
\hline$\% \wedge 0, \varepsilon$ & ErV & نـعــــم \\
\hline$\% 1 \varepsilon, 7$ & Vr & كســالا \\
\hline$\%$ & $0 . \cdot$ & المجموع \\
\hline
\end{tabular}

1- الإعلانات عبر الإذاعة تلفت انتباه الجمهور: دلت نتائج البحث على ان ان الإعلانات الاذاعية (احياناً)

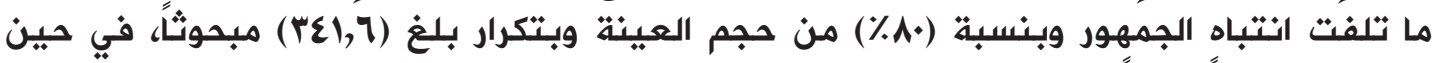

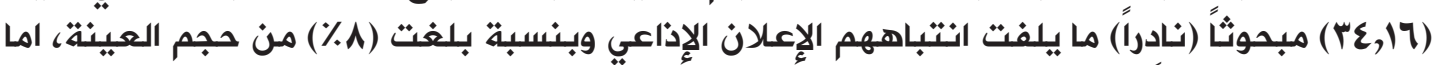

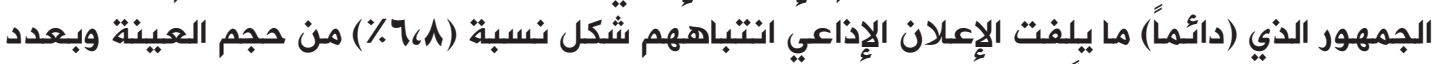

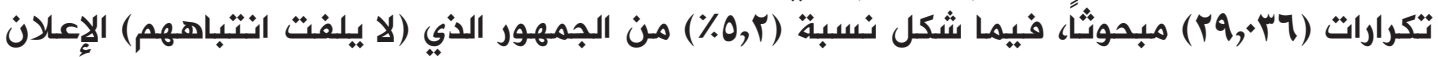




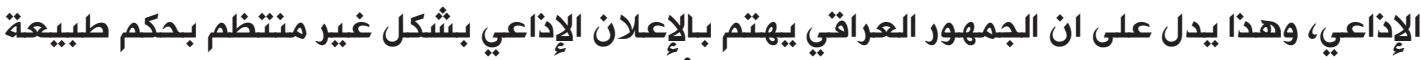

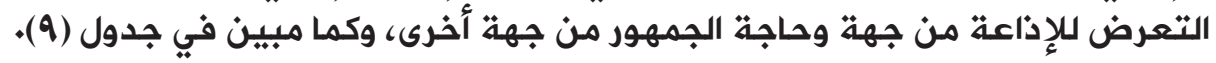
جدول (9) يوضس الإعلانات الاذاعية تلفت انتباه الجمهور

\begin{tabular}{|c|c|c|}
\hline النسبة المئوية النسة & التكرارات & الإعلانات الإذاعية تلفت انتباه الجمهور \\
\hline$\% \wedge \cdot,+9$ & rer & 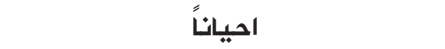 \\
\hline$\% \vee, ৭ 7$ & $r \varepsilon$ & 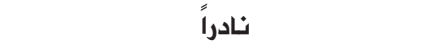 \\
\hline$\% \nearrow, \wedge$. & rq & 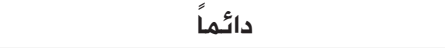 \\
\hline$\% 0,10$ & rr & لا تلفت انتباههم \\
\hline$\%$ & $\varepsilon r Y$ & 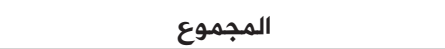 \\
\hline
\end{tabular}

ه-أسباب الاستماع للإعلان الإذاعي: كشفت نتائج البحث عن ان معان معظم افراد العينة والبالغ عددهم

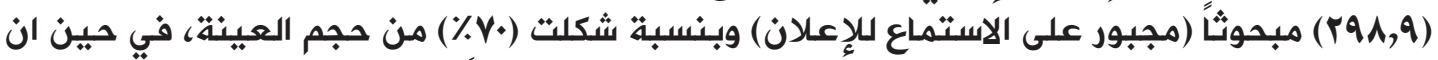

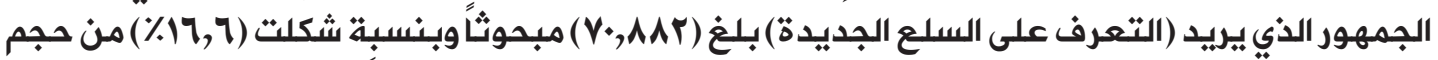

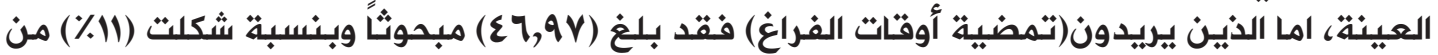

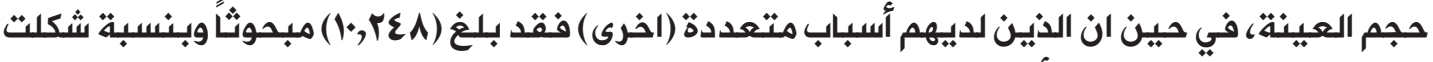

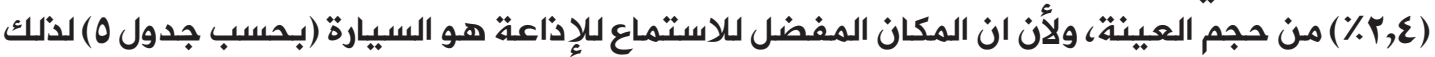

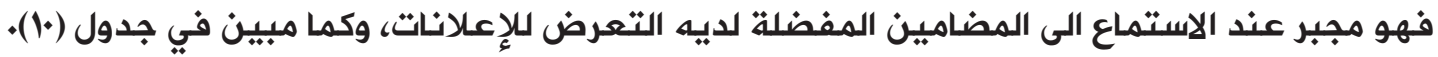

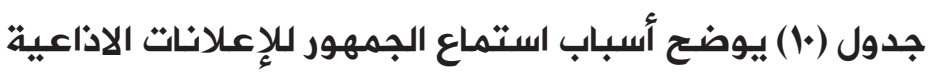

\begin{tabular}{|c|c|c|}
\hline النسبة المئويـة & التكرارات & أسباب الاستماع للإعلانات الاذاعية \\
\hline$\% v \cdot,+r$ & r99 & مجبور على الاستماع للإعلان \\
\hline$\% 17,74$ & n & التعرف على السلع الجديدة \\
\hline$\% 11, \cdot 1$ & $\varepsilon \vee$ & تمضية أوقات الفراغ \\
\hline$\% r, r \varepsilon$ & 1. & 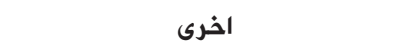 \\
\hline$\%$ & ETr & المجموع \\
\hline
\end{tabular}

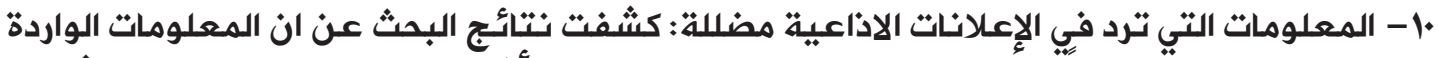

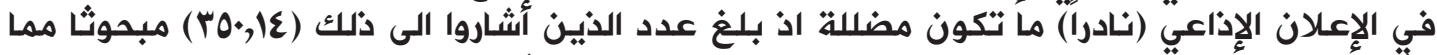

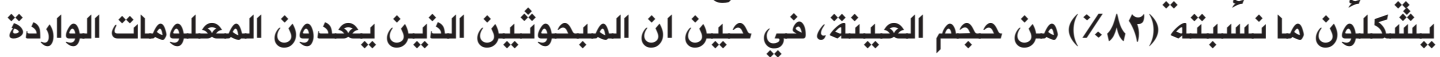

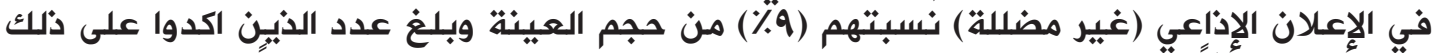

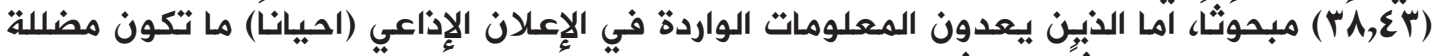

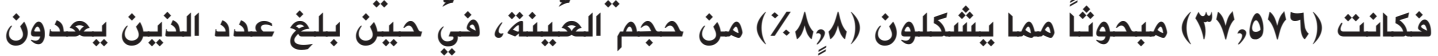

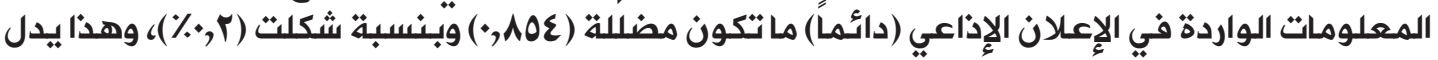

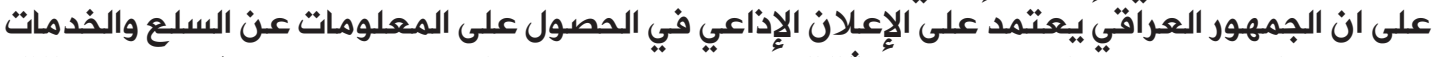

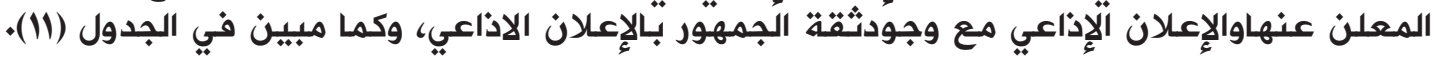


جدول (II) يوضح تضليل المعلومات الواردة في الإعلانات الاذاعية

\begin{tabular}{|c|c|c|}
\hline النسبة المئوية النسة & 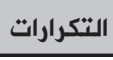 & تضليل المعلومات الواردة في الإعلان الإذاعي \\
\hline$\% \wedge r, r$. & rol & نادراً \\
\hline$\% \wedge, q$. & ra & غير مضللة \\
\hline$\% \wedge, 7 \vee$ & rv & 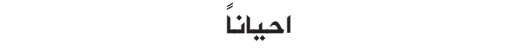 \\
\hline$\%, r r$ & 1 & دائماً \\
\hline$\%$ & $\varepsilon r Y$ & المجموع \\
\hline
\end{tabular}

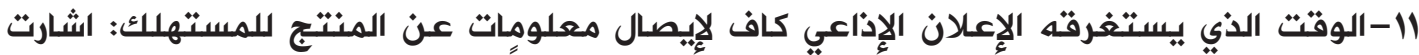

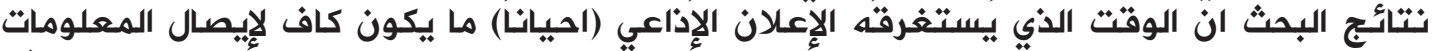

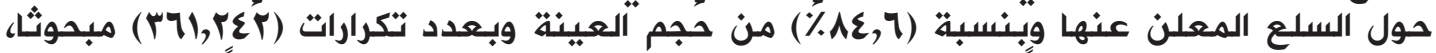

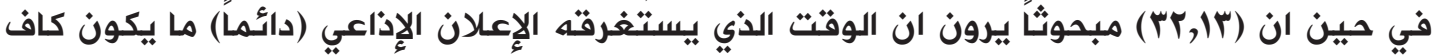

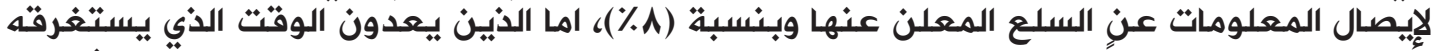

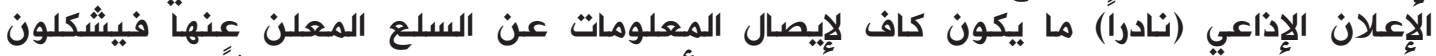

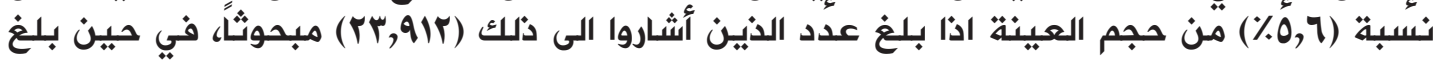

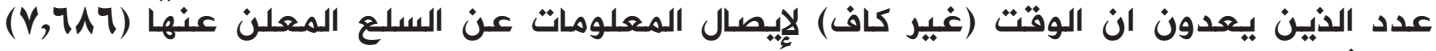

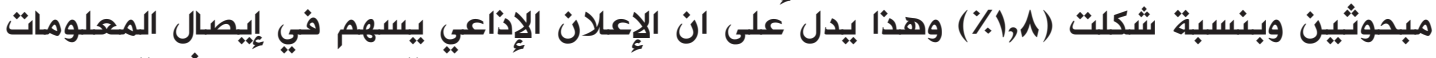

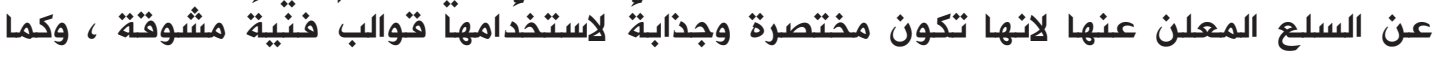

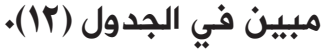

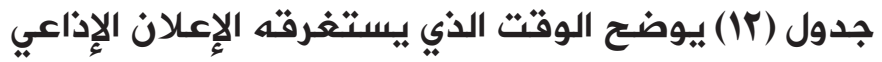

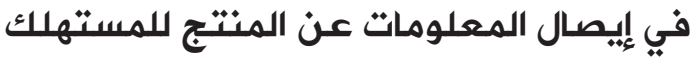

\begin{tabular}{|c|c|c|}
\hline النسبة المئويـة & التكرارات & الوقت الذي يستغرقه الإعلان الإذاعي \\
\hline$\% \wedge \varepsilon, \vee \wedge$ & rar & احيانًا \\
\hline$\% \vee, ০$. & rt & دائماً \\
\hline$\% 0, \wedge 0$ & ro & 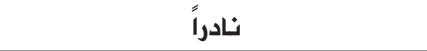 \\
\hline$\% 1, \wedge \vee$ & $\wedge$ & غير كافي \\
\hline$\%$ & $\varepsilon r Y$ & المجموع \\
\hline
\end{tabular}

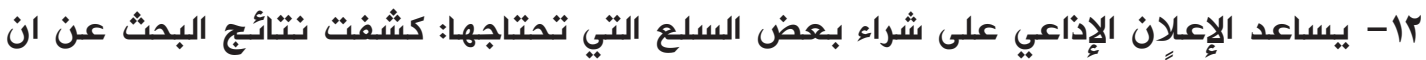

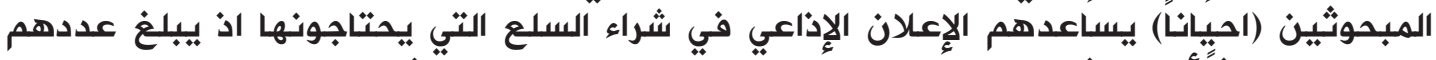

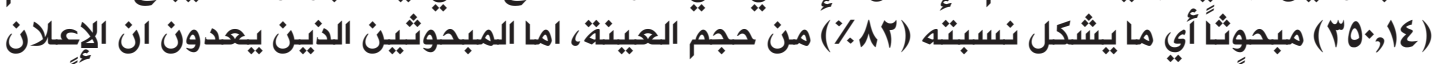

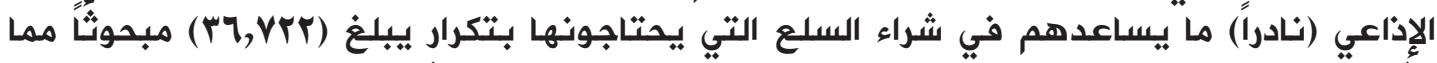

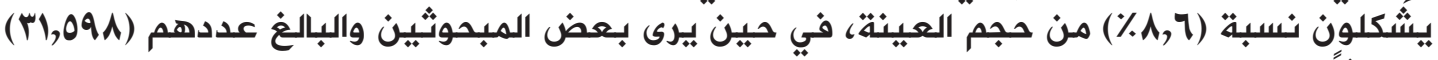

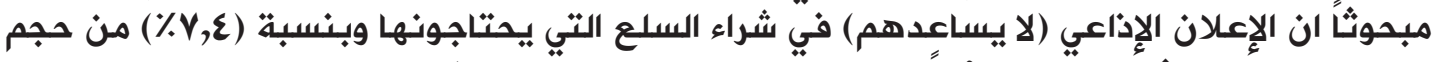

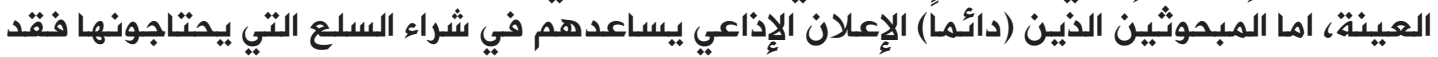

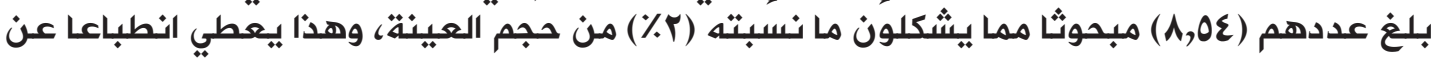

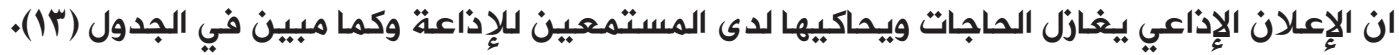


جدول (rا) يوضح مساعدة الإعلان الإذاعي الجمهور على شراء بعض السلـع التي تحتاجها

\begin{tabular}{|c|c|c|}
\hline النسبة المئوية & التكرارات & مساعدة الإعلان الإذاعي للجمهور \\
\hline$\% \wedge 1,9 \vee$ & ro. & 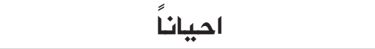 \\
\hline$\% \wedge, 7 \vee$ & rr & 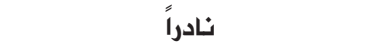 \\
\hline$\% \vee, \varepsilon q$ & rt & لا يساعدني \\
\hline$\%, \wedge \vee$ & $\wedge$ & دائماً \\
\hline$\%$ & $\varepsilon r r$ & المجموع \\
\hline
\end{tabular}

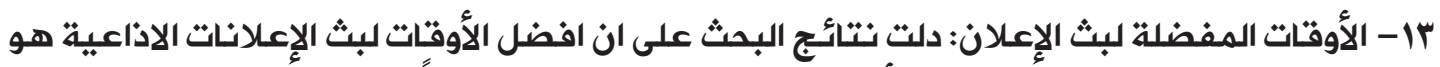

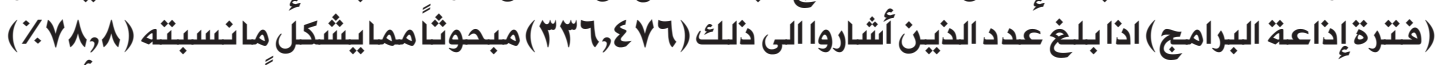

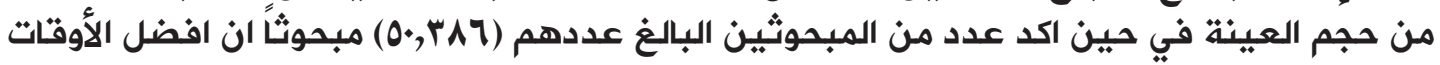

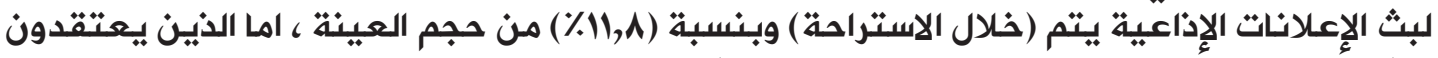

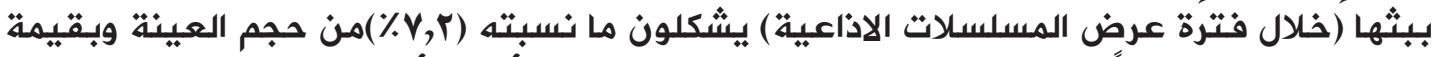

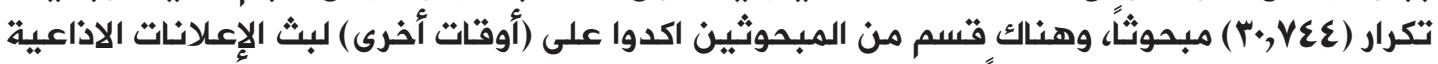

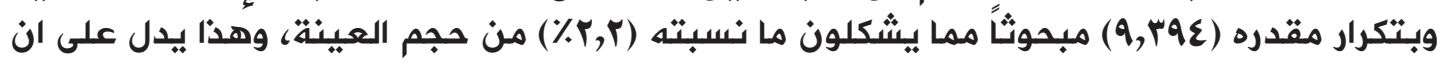

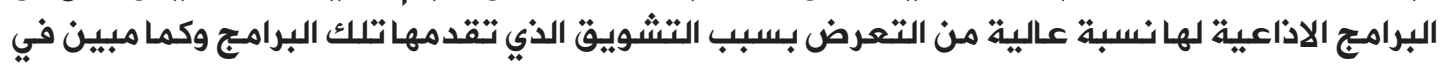

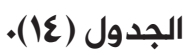

جدول (ع) ) يوضح الأوقات المفضلة لبث الإعلان الاذاعي

\begin{tabular}{|c|c|c|}
\hline النسبة المئوية & التكرارات & الأوقات المفضلة لبث الإعلان الاذاعي \\
\hline$\% \vee \wedge, 79$ & בrr & خلال فترة عرض البرامج \\
\hline$\% 11,9 \varepsilon$ & 01 & خلال فترة الاستراحة \\
\hline$\% \vee, r q$ & r & خلال فترة عرض المسلسلات الاذاعية \\
\hline$\%, 11$ & 9 & أوقات اخرى \\
\hline$\%$ & $\varepsilon r \mathrm{r}$ & المجموع \\
\hline
\end{tabular}

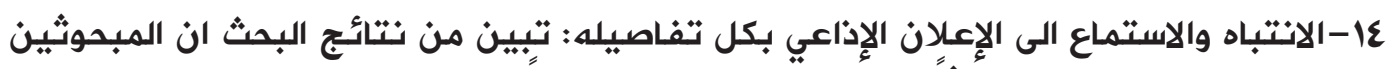

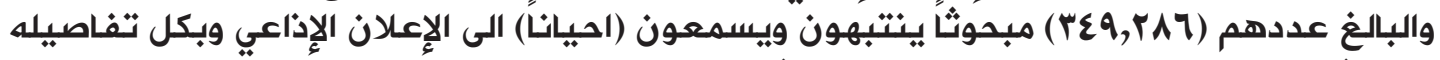

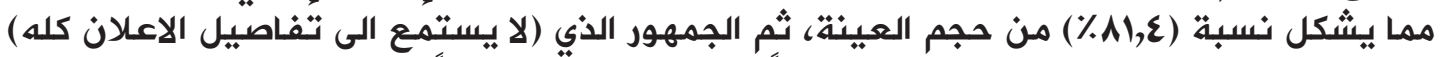

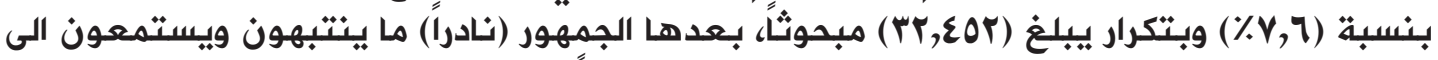

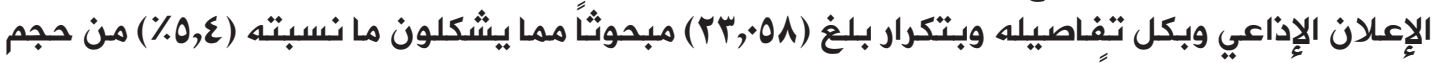

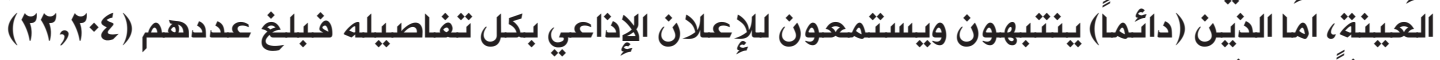

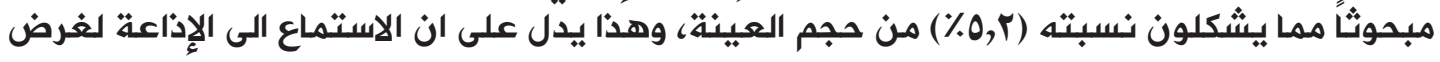
التسلية والامتاع وليس لغرض الئون نسته الانتباه وكسب المعلومات وكما مبين في الجدول (10). 
جدول (10) يوضـح انتباه واستماع الجمهور الى الإعلان الإذاعي بكل تفـاصبله

\begin{tabular}{|c|c|c|}
\hline النسبة المئويـة & 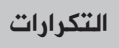 & الانتباه والاستماع الى الإعلان الإذاعي بكل تفاصيله \\
\hline$\%$ \%l, $\mathrm{Yr}$ & req & 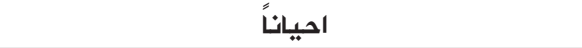 \\
\hline$\% \vee, \vee r$ & r & لا استمع لكل التفاصيل \\
\hline 0,49 & r & 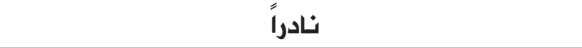 \\
\hline$\% 0,01$ & rt & دائماً \\
\hline$\%$ & $\varepsilon r Y$ & 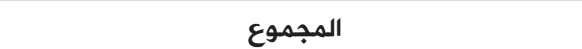 \\
\hline
\end{tabular}

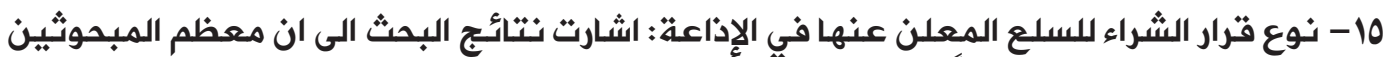

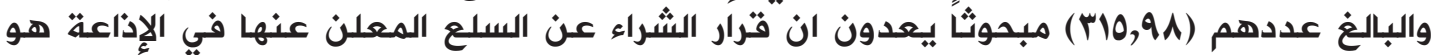

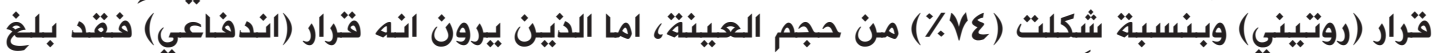

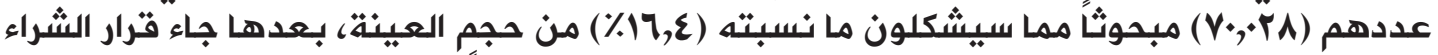

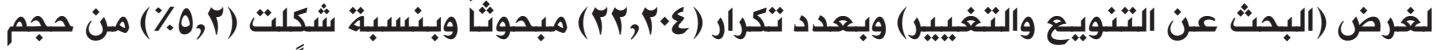

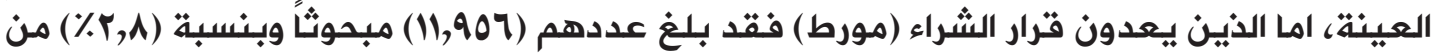

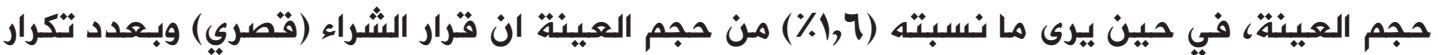

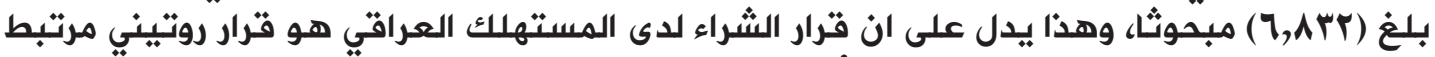

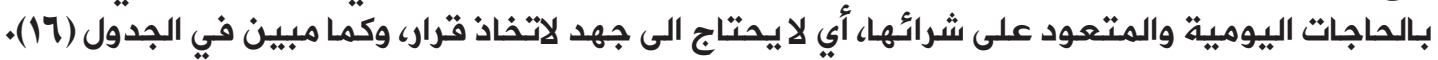

جدول (17) يوضح نوع قرار الشراء للسلع المعلن عنها في الإذاعة

\begin{tabular}{|c|c|c|}
\hline النسبة المئوية & التكرارات & نوع قرار الشراء للسلع المعلن عنها في الإذاعة \\
\hline$\% \vee \varepsilon, \cdot 1$ & ril & روتيني \\
\hline$\% 17, \% 9$ & v. & اندفاعي \\
\hline$\% 0,10$ & rr & البحث عن التنويع والتغيير \\
\hline$\%, r, \wedge 1$ & ir & مورط \\
\hline$\% 1,7 \varepsilon$ & $\checkmark$ & قصري \\
\hline$\%$ & $\varepsilon r r$ & المجموع \\
\hline
\end{tabular}

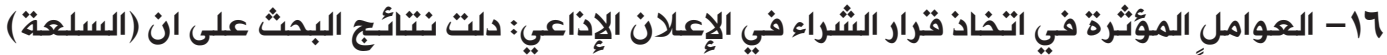

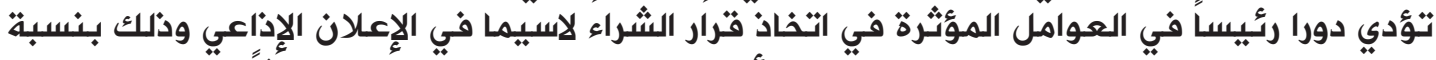

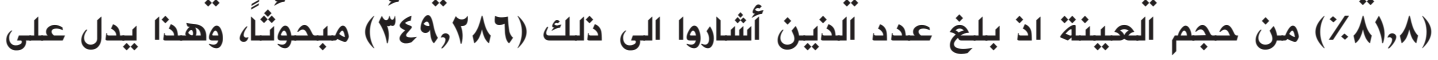

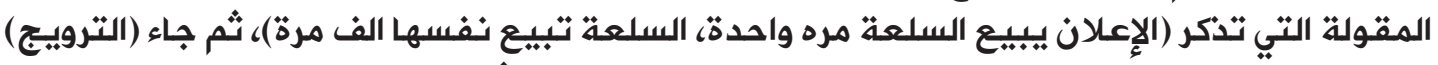

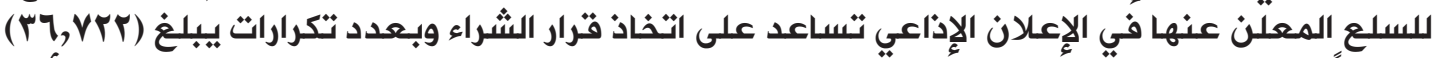

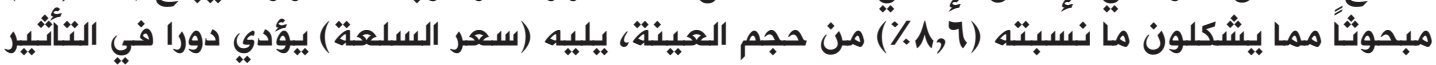

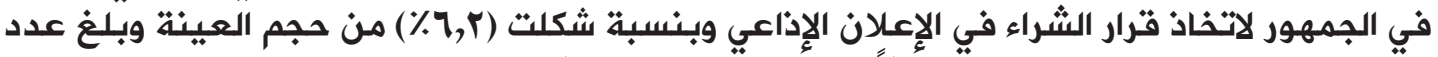

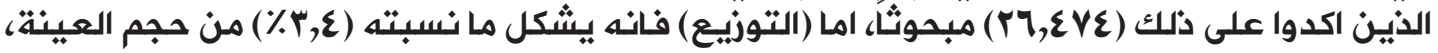

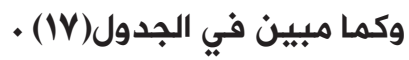


جدول (IV) يوضع العوامل المؤثرة على اتخاذ قرار الشراء في الإعلان الإذاعي

\begin{tabular}{|c|c|c|}
\hline النسبة المئوية & 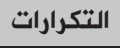 & العوامل المؤثرة على اتخاذ قرار الشراء في الإعلان الإذاعي \\
\hline$\% \wedge I, V \mu$ & rहq & السلعة \\
\hline$\% \wedge, \neg \vee$ & $r v$ & 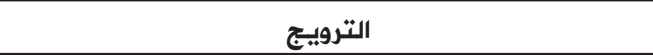 \\
\hline$\% 7,9$ & rq & السعر \\
\hline$\%$ \%,01 & 10 & 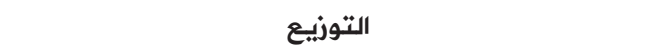 \\
\hline$\%$ & $\varepsilon r V$ & 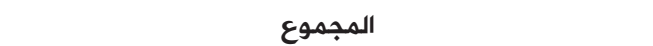 \\
\hline
\end{tabular}

المحور الثاني: العلاقتات الارتباطية بـسبب الفروض

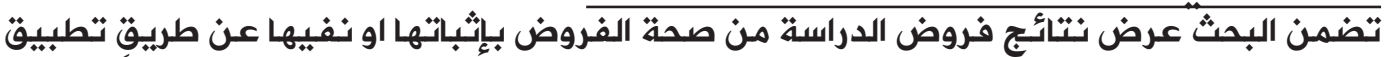
معامل الارتباط الفـا-كرو نباخ Cranbachs-Alpha للكشف عن فروق الدالة احصائياً في اراء افراد العينة (الجمهور العراقي مجتمع الدراسة) اذ جرى وضع الخصائص الديموغرافية للمبحوثين

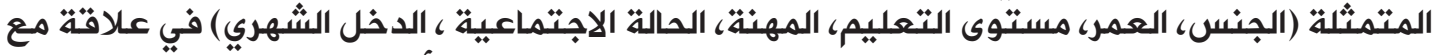

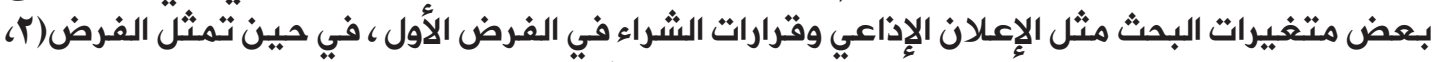

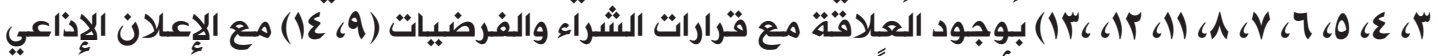

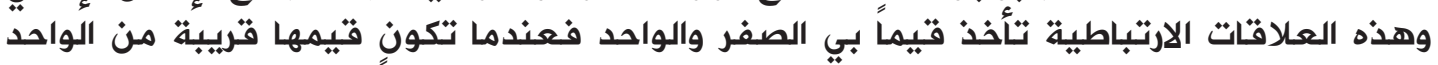

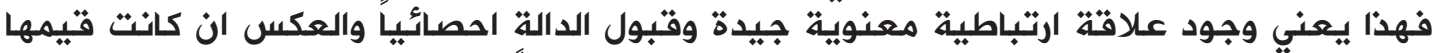
تققترب من الصفر فهذا يعني ضعف الارتباط المعنوي احصائياً ورفض الدالة وكما مبين في ادني ادناه.

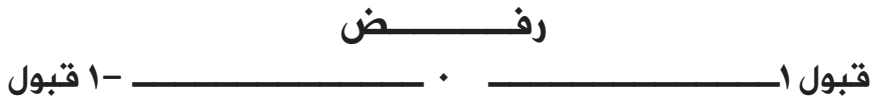

الفرض الأول: توجد فروق ذات دلالة إحصائبية بين العوامل الديموغرافية (الجنس، العمر) المستوى التعليمي، الحالة الاجتماعية، الدخل الشهري، المهنة ) والاعلان الإذأاعي وقرارات الشراء.

لاختبار صحة الفرضبة جرى استخدام الفا-كرو نباخ Cranbachs-Alpha لمعرفة مدى

الارتباط المعنوي بين المتغير المستقل (العناصر الديموغرافية) والمتغير التابع (الإعلان

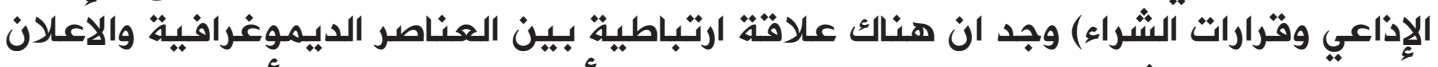

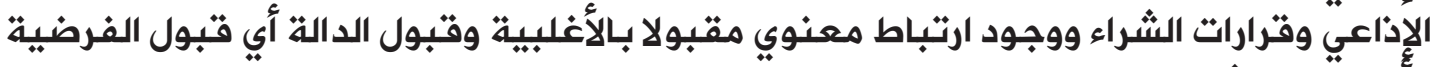

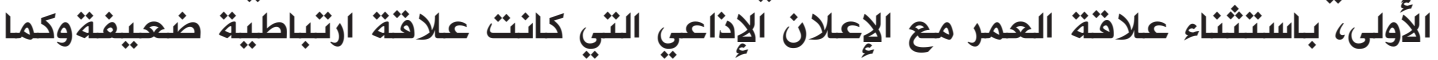
مبين في الجدول (IA) ماكئ 
جدول(1) بوضح معامل الارتباط للفرضبة الاولى

\begin{tabular}{|c|c|c|c|c|c|}
\hline 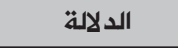 & النتيجة & معنوية معامل ارتباط الرتب & التابع & المستقل & الفرضية الفية \\
\hline \multirow{12}{*}{ الدلة بالأغلبية } & قبول الدالة & • & \multirow{6}{*}{ الإذاعـــــــان } & الجنس الجن & \multirow{12}{*}{ الاولــــى } \\
\hline & رفض الدالة & r & & 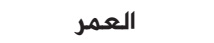 & \\
\hline & قبول الدالة & .091 & & مستوى التعليم & \\
\hline & قبول الدالة & $\cdot, \wedge 9$. & & الحالة الاجتماعية & \\
\hline & قبول الدالة & , ¿૦. & & الدخل الشهري & \\
\hline & قبول الدالة & •,乏ץ. & & المهنة & \\
\hline & قبول الدالة & , Yr. & \multirow{6}{*}{ قترارات } & 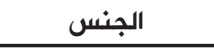 & \\
\hline & قبول الدالة & , rA^ & & العمر العر & \\
\hline & رفض الدالة & , rr. & & مستوى التعليم & \\
\hline & قبول الدالة & , Yrq & & الحالة الاجتماعية & \\
\hline & قبول الدالة & , ^^ץr & & الدخل الشهري & \\
\hline & قبول الدالة & , Yo. & & المهنة & \\
\hline
\end{tabular}

الفرضية الثانبة: توجد فروق ذات دلالة إحصائبة بين الاستماع للإذاعة وقرارات الشراء.

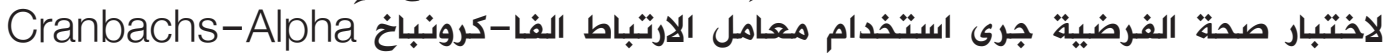

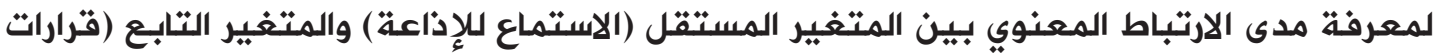

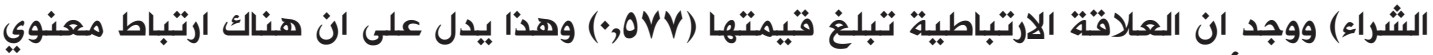
وقبول الدالة أي قبول الفرضية وكما مبين في الجدول (19). جدول(19) بوضـح معامل الارتباط للفرضبية الثانبية

\begin{tabular}{|c|c|c|c|c|}
\hline الدلالـــــــــــة & معنويـة معامل & التتابـع & المستقل & الفرضية \\
\hline قبول الدالة وجود معنوي & , OrV & قرارات الشراء & الاستماع للإذذاعة & الفرضية الثانية \\
\hline
\end{tabular}

الفرضية الثالثة: توجد فروق ذات دلالة إحصائية بين الوقت الذي يستغرقه الإعلان الإذاعي

لاختبار صحة الفرضية جرى استخدام معامل الارتباط الفا-كرونباخ وقرارات الشراء. لمعرفـة مدى الارتباط المعنوي بين المتغير المستقل (وقت الاعلان) والمتغير التابع (قرارات

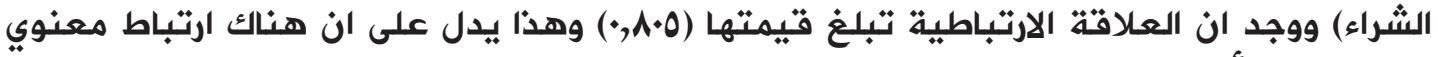

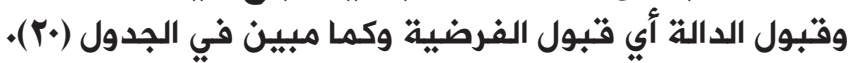

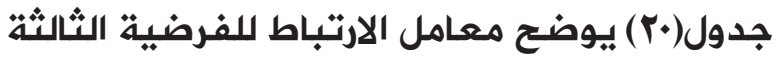

\begin{tabular}{|c|c|c|c|c|}
\hline الدلالـــــــــــة & معنويـة معامل & التابـع & المستقل & الفرضية \\
\hline قبول الدالة وجود & $\cdot, \Lambda \cdot 0$ & قرارات الشراء & وقت الإعلان & الفرضية الثالثـــــة \\
\hline
\end{tabular}


الفرضية الرابعة (توجد فروق ذات دلالة إحصائية بين التعرض المستمر للإعلان الإذاعي وقرارات الشراء).

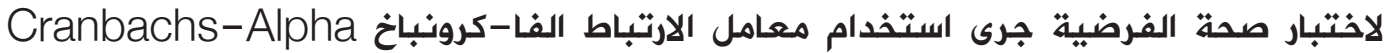

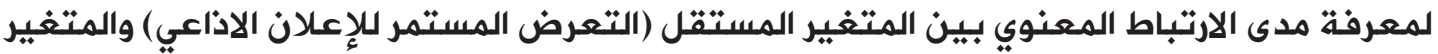

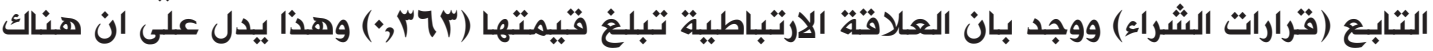

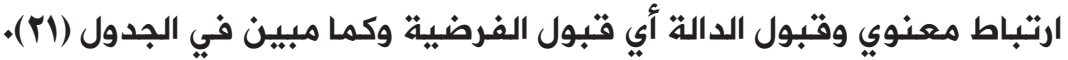

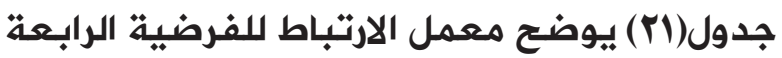

\begin{tabular}{|c|c|c|c|c|}
\hline الدلالــــــــــة & معنوية معامل ارتباط الرتب & التابـع & المستقل & الفرضبية \\
\hline قبول الدالة وجود & זרז, & قرارات الشراء & الاستماع للإذذاعـــة & الفرضية الرابـعـــــة \\
\hline
\end{tabular}

الفرضية الخامسة (توجد فروق ذات دلالة إحصائية بين مدى ثقة الجمهور بالإعلانات الاذاعية وقرارات الشراء).

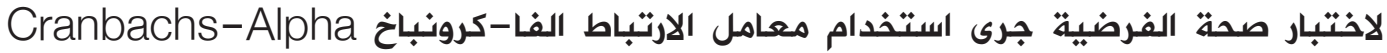

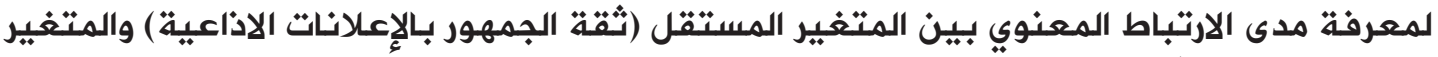

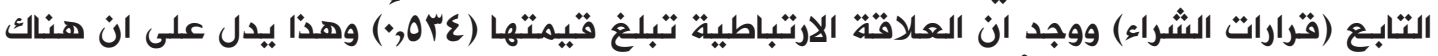

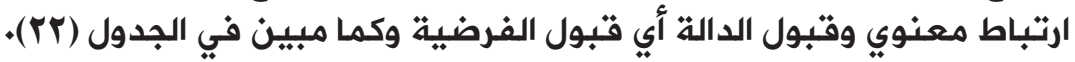
جدول(r) يوضع معامل الارتباط للفرضية الخامسة

\begin{tabular}{|c|c|c|c|c|}
\hline الدلالـــــــــــة & معنوية معامل & التابع & المستقل & الفرضية \\
\hline قببول الدالة وجود معنوي & & قرارات الشراء & بالاعلانات الإذاعية & الفرضية الخامســـة \\
\hline
\end{tabular}

الفرضية السادسة (توجد فروق ذات دلالة إحصائية بين المعلومات الواردة في الإعلانات الاذاعية وقرارات الشراء).

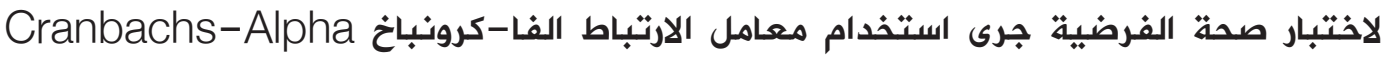

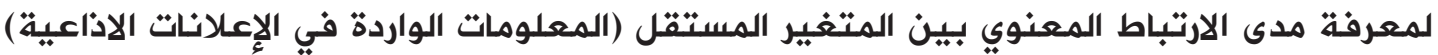

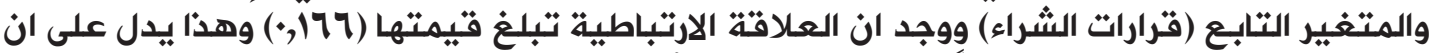

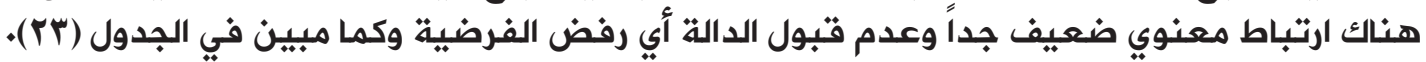

\section{جدول(r/T) يوضح معامل الارتباط للفرضية السادسة}

\begin{tabular}{|c|c|c|c|c|}
\hline الدلالـــــــــة & ارتباط الرتب معامل & التابع & المستقل & الفرضية \\
\hline قبول الدالة وجود ارتباط & $\cdot, 177$ & قترارات الشراء & الاععلانات الإذاعية الواردة في & الفرضية السادســــ \\
\hline
\end{tabular}


الفرضية السابـة (توجد فروق ذات دلالة إحصائية بين مساعدة الإعلان الإذاعي الجمهور في التعرف على السلع التي يبحث عنها وقرارات الشراء).

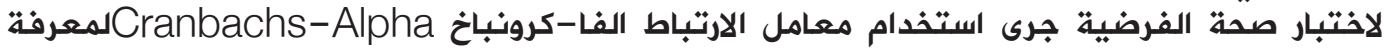

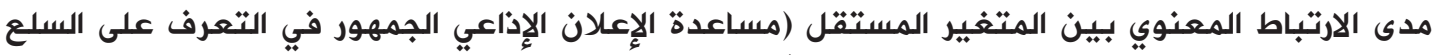

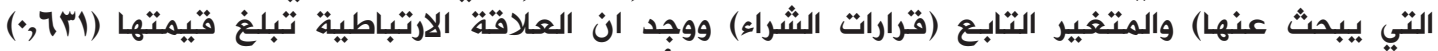

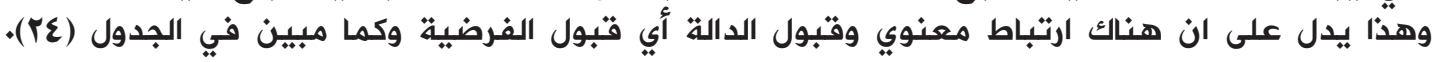

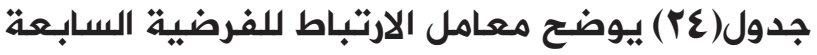

\begin{tabular}{|c|c|c|c|c|}
\hline الدلالـــــــــــة & معنوية معامل & التابـع & المستقل & الفرضية \\
\hline قبول الدالة وجود & וTו", & قرارات الشراء & 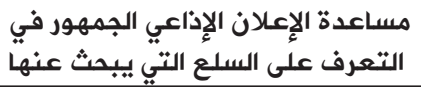 & الفرضية السابـعـــة \\
\hline
\end{tabular}

الفرضية الثامنة (توجد فروق ذات دلالة إحصائية بين الانتباه والاستماع الى الإعلان الإذاعي بكل تفـاصيله وقرارات الشـراء).

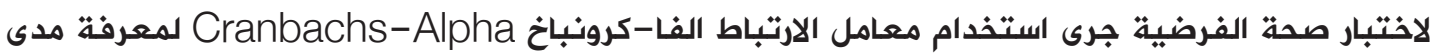

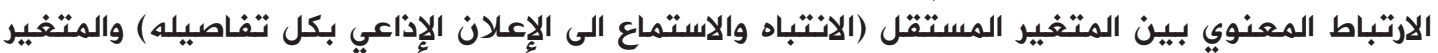

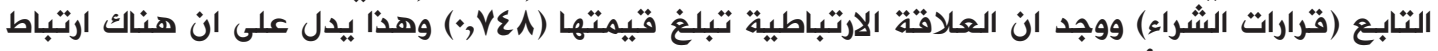

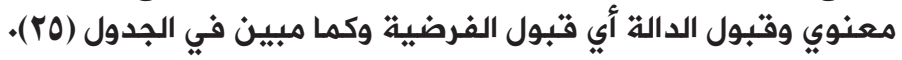
جدول(rO) يوضح معامل الارتباط للفرضية الثامنة

\begin{tabular}{|c|c|c|c|c|}
\hline الدلالــــــــــة & معنوية معامل & التابـع & المستقل & الفرضية \\
\hline قبول الدالة وجود &,$\vee \vee \varepsilon \wedge$ & قرارات الشراء & 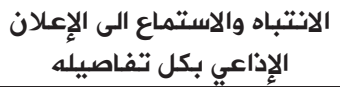 & الفرضية الثامنـــــــ \\
\hline
\end{tabular}

الفرضية التاسعة (توجد فروق ذاتد لالة إحصائية بيـن قرارالشراء للسلع المعلن عنهافي الإذاعة والاعلان

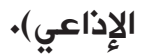
لاختبار صحة الفرضية جرى استخدام معامل الارتباط الفا-كرونباخ Cranbachs-Alpha لمعرفة مدى الارتباط المعنوي بين المتغير المستقل (قرار الشراء للسلع المعلن عنها في الإذاعة) والمتغير الإنير

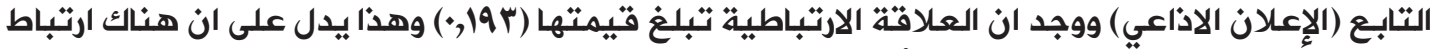

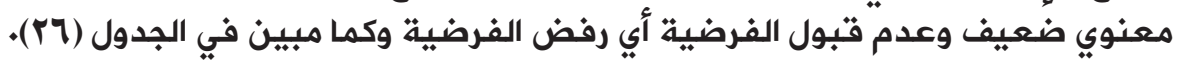

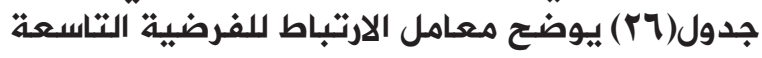

\begin{tabular}{|c|c|c|c|c|}
\hline الدلالــــــــــة & معنويـة معامل & التابـع & المستقل & الفرضية \\
\hline قبول الدالة وجود ارتباط & •,19r & الإعاء الإذاعلان & قرار الشراء للسلع المعلن عنها في & الفرضية التـاســـــــة \\
\hline
\end{tabular}

الفرضية العـاشرة (توجد فروق ذات دلالة إحصائية بين العوامل المؤثرة على اتخاذ قـرار الشراء والاعلان

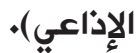
لاختبار صحة الفرضية جرى استخدام معامل الارتباط الفـا-كرونباخ Cranbachs-Alpha لمعرفة مدى

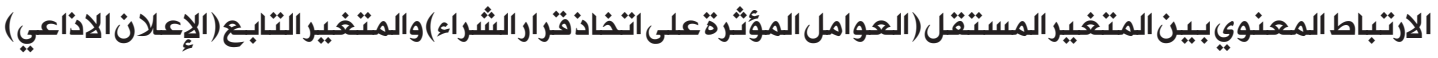


ووجد ان العلاقة الارتباطية تبلغ قيمتها (·r, (·) وهذا يدل على ان هناك ارتباط معنوي ضعيف وعدم قبول

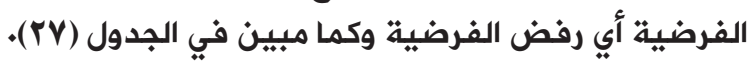

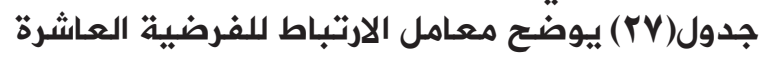

\begin{tabular}{|c|c|c|c|c|}
\hline الدلالــــــــــة & معنويـة معامل ارتباط الرتب & التابـع & المستقل & الفرضية \\
\hline قبول الدالة وجود ارتباط & , rr. & الإإعلان إعي & العوامل المؤثرة على اتخاذ قرار & الفرضية العـاشرة \\
\hline
\end{tabular}

الفرضية الحادية عشرة (لاتوجد فروق ذات دلالة إحصائية بين المكان الذي يستمع فيه الجمهور للإعلان الاذاعي وفرارات الشراء). لاختبار صحة الفرضية جرى استخدات الإم معامل الارتباط الفـا-كرونباخ Cranbachs-Alpha لمعرفة

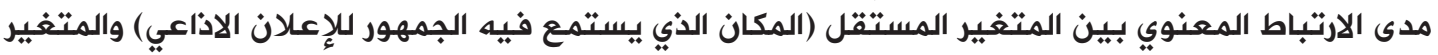

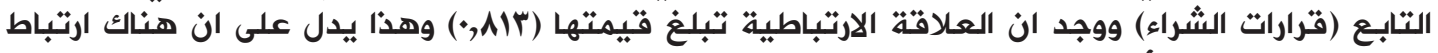

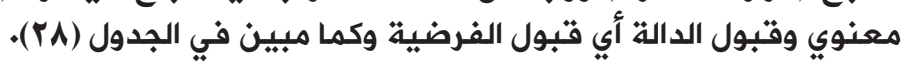

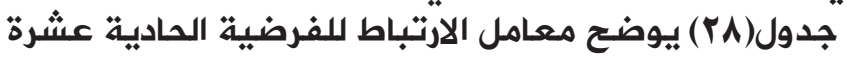

\begin{tabular}{|c|c|c|c|c|}
\hline الدلالــــــــــة & معنوية معامل & التابـع & المستقل & الفرضية \\
\hline قبول الدالة وجود ارتباط & • & قرارات الشراء & المكان الذي يستمـ فيه الجمهور & الفرضية العـاشرة \\
\hline
\end{tabular}

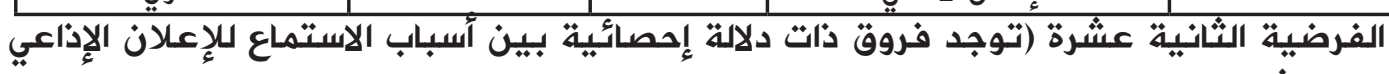
وقرارات الشراء).

لاختبار صحة الفرضية جرى استخدام معامل الارتباط الفا-كرونباخ Cranbachs-Alpha

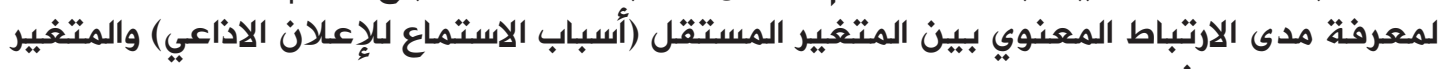

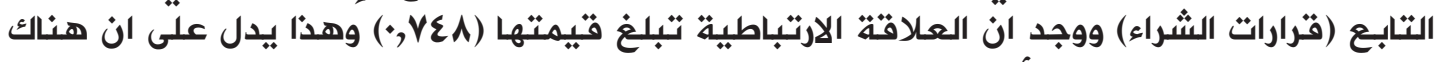

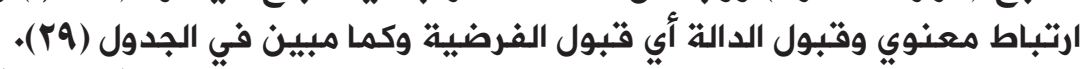

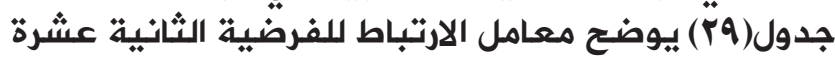

\begin{tabular}{|c|c|c|c|c|}
\hline الدلالـــــــــــة & معنوية معامل & التابـع & المستقل & الفرضية \\
\hline قبول الدالة وجود ارتباط & $\cdot, \vee \varepsilon \wedge$ & قرارات الشراء & أسباب الاستماع للإعلان الاذاعي & الفرضية الثانية \\
\hline
\end{tabular}

المحور الثالث: العلافتة المؤثرة بين الإعلان الإذاعي والتعرض للإذذاعة وقرارات الشراء.

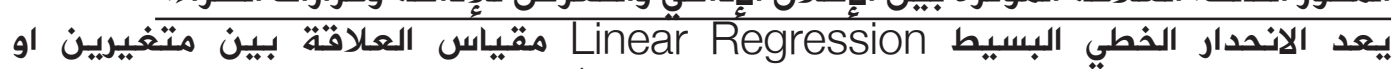

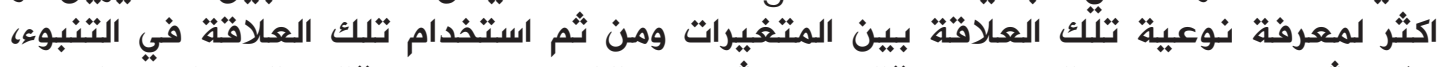

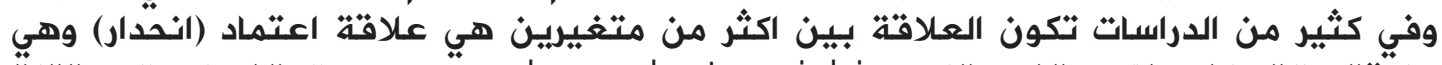

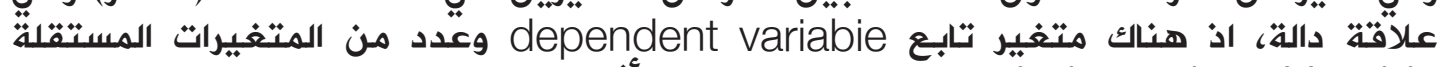
Independent Variable المعتمد (Walid Abdul Rahman,1430e,p-33).

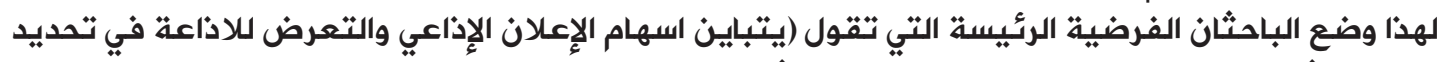

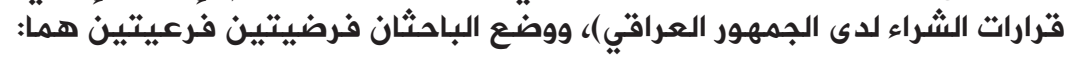


الفرض الفرعية الاولى: يـتباين تأثير الإعلان الإذاعي على الجمهور عن طريقت تقديم المعلومات عن السلع

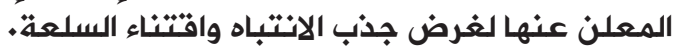

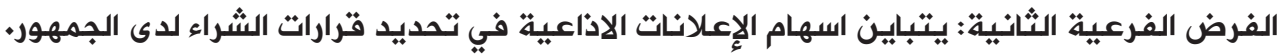

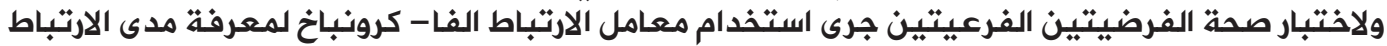

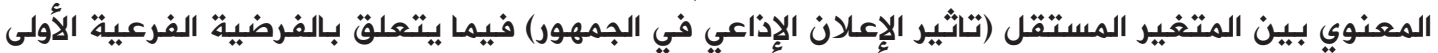

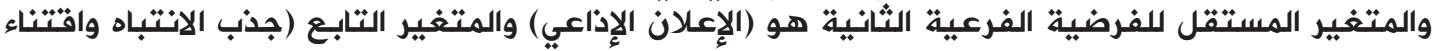

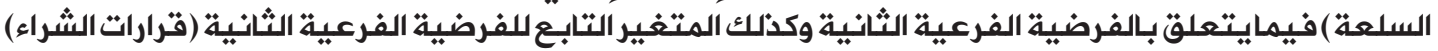

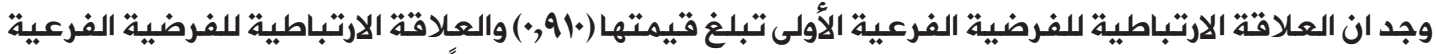

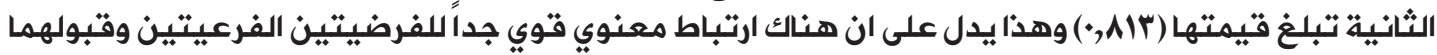

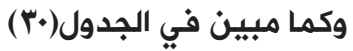

جدول(•r) يوضع معامل الارتباط الفرضيتان الفرعيتان

\begin{tabular}{|c|c|c|c|c|}
\hline الدلالـــــــــة & معنوية معامل ارتباط الرتب & التابع & المستقل & الفرضية \\
\hline قبول الدالة وجود ارتباط &, 91. & واقتناء السلعة الانتباه & تأثثير الإعلان الإذاعي & الفرضية الفرعية \\
\hline قبول الدالة وجود ارتباط & 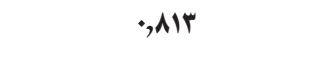 & قرارات الشراء & الإعلان الاذاعي & الفرضية الفرعية \\
\hline
\end{tabular}

إذ بين حساب معامل التصديد (R) للفرضية الرئيسة ومعامل التحديد مربـع قيمة معامل التحديد وان معامل الارتباط بين الإعلان الإذاعي والتعرض للإذذاعة هو (Rquare)

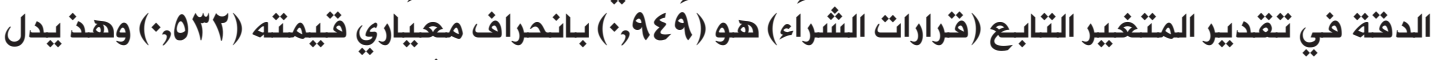

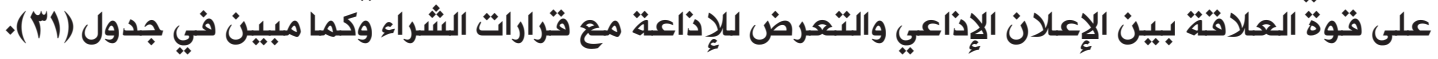

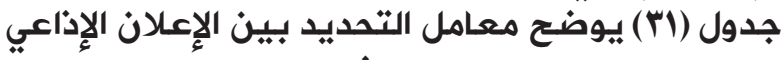

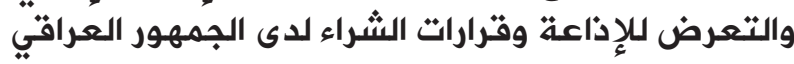

\begin{tabular}{|c|c|c|c|}
\hline $\begin{array}{c}\text { Std Error of the Estimate } \\
\text { الانحراف المعياري }\end{array}$ & $\begin{array}{l}\text { R_square } \\
\text { R__مربع }\end{array}$ & $\begin{array}{c}R \\
\text { معامل التصديد }\end{array}$ & $\begin{array}{c}\text { Model } \\
ت\end{array}$ \\
\hline rorr &, $9 \varepsilon q$ & , qVع & الفرضية الرئيسة \\
\hline
\end{tabular}

على ان معادلة الانحدار تكون على النحو الآتّي: $Y=0,150 X_{1}+0,957 X_{2}$ إذ إن =Y •X1

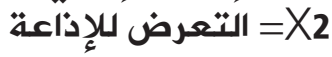

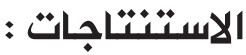

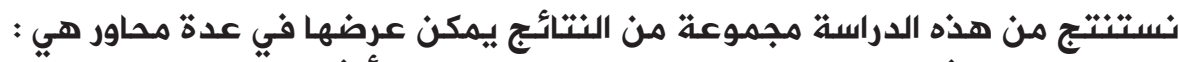

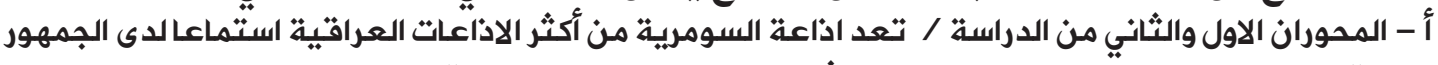

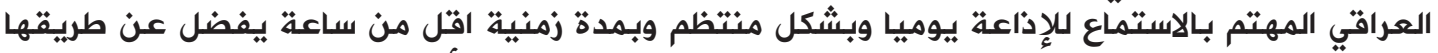

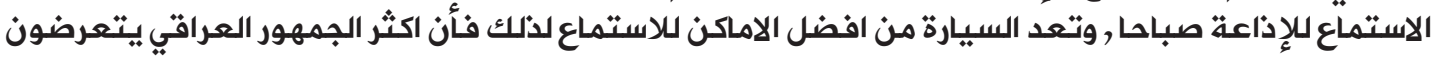


للإعلانات الاذاعية بشكل منتظم عند الاستماع للإذذاعة وتلفت انتباههم لانهم مجبرين على الاستماع

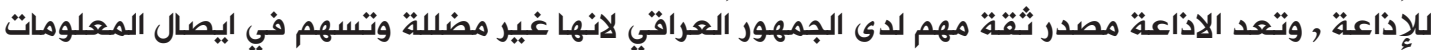

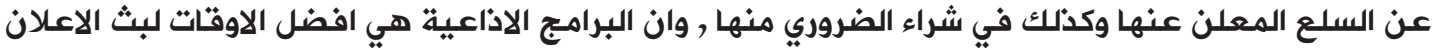

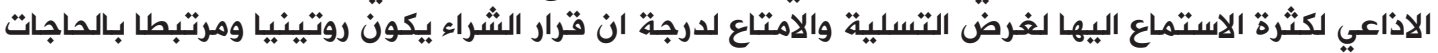

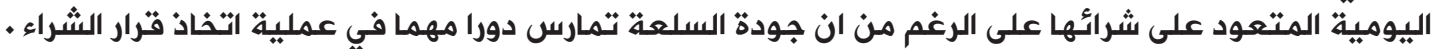

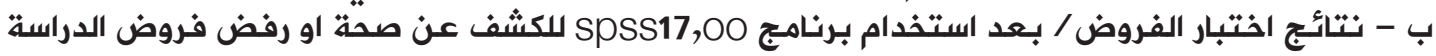
تبين ما يآني :

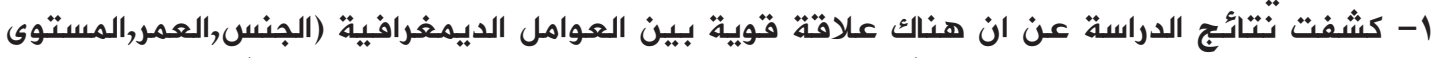

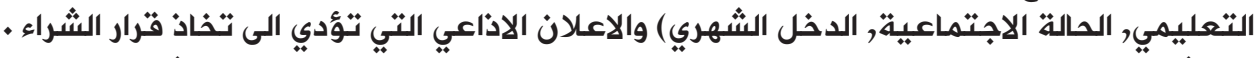

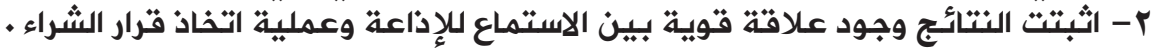

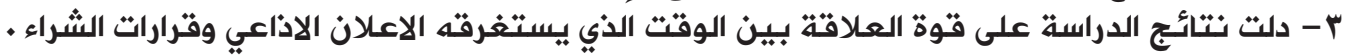

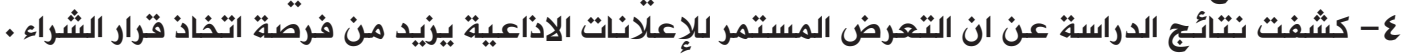

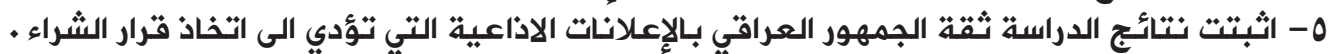

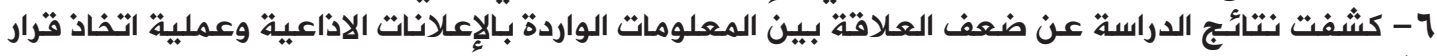
الشراء V- اثبتت نتائج الدراسة مساعدة الاعلان الاذاعي الجمهور العراقي في معرفة السلع التي يبحث عنها والتي

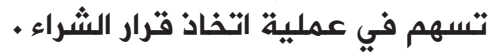

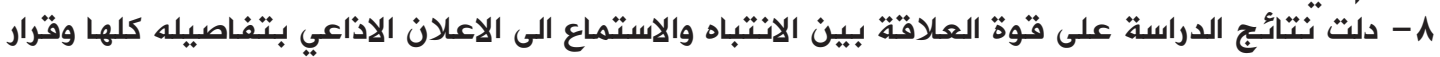
الشراء

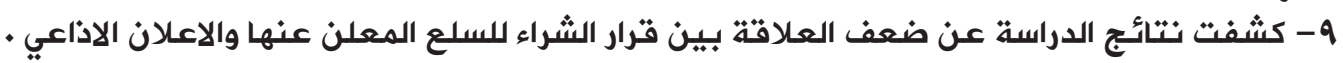

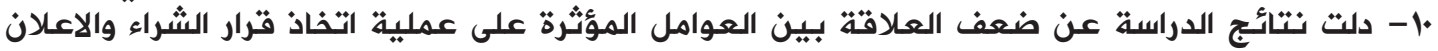

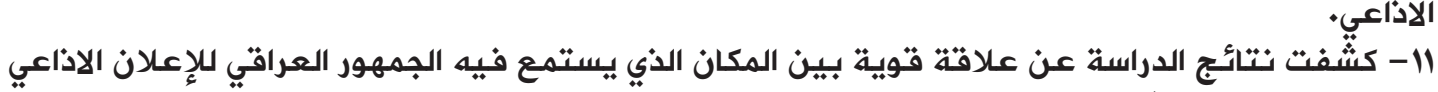

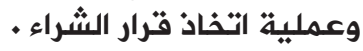
rا- دلت نتائج الدراسة على وعلى وجود علارقة ارتباطية واضحة بين اسباب الاستماع للإعلان الاذاعي وقرار الشراء

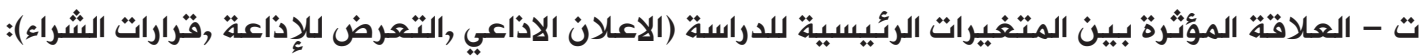

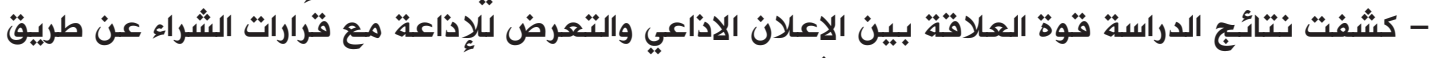

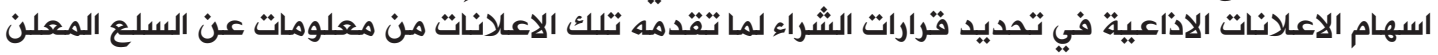

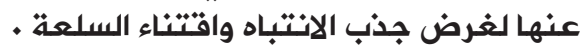

\footnotetext{
المصادر

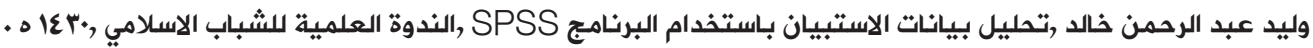

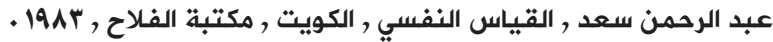

Walid Abdel Rahman Khaled,Analysis of questionnaire data using program SPSS,Scientific Sym.posium for Islamic youth , 1430e

Abdul Rahman Saad, Self - measurement, Kuwait, Al falah Library , 1983 